Deniz, A. ve Gönen, M. (2021). Kitap okuma etkinliklerinin ve resimli öykü kitaplarının niteliği ile sosyoekonomik açıdan dezavantajlı çocukların dil gelişimleri arasındaki ilişki. Ana Dili Eğitimi Dergisi, 9(4), 1376-1399.

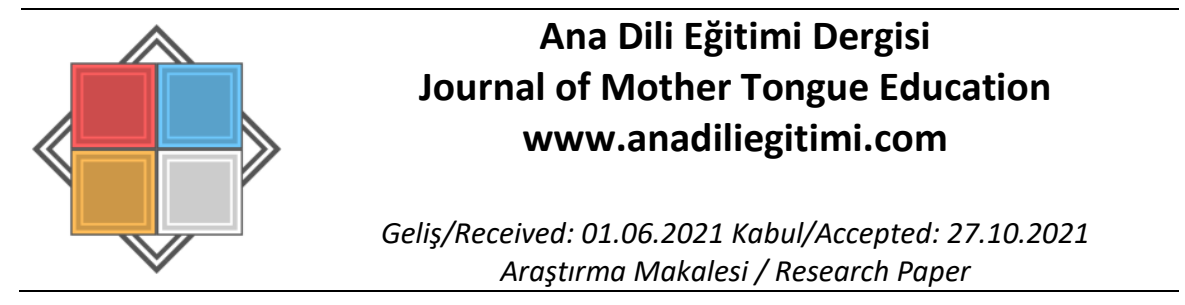

\title{
Kitap Okuma Etkinliklerinin ve Resimli Öykü Kitaplarının Niteliği ile Sosyoekonomik Açıdan Dezavantajlı Çocukların Dil Gelişimleri Arasındaki ílişki*
}

\author{
Ayşegül DENiz ${ }^{* *}$ \\ Mübeccel GÖNEN ${ }^{* * *}$
}

\begin{abstract}
Öz
Bu araştırmada kitap okuma etkinliklerinin ve resimli öykü kitaplarının niteliği ile okul öncesi eğitim alan alt sosyoekonomik düzeydeki ailelerden gelen çocukların alıcı ve ifade edici dil sözcük bilgileri ve dil gelişimleri arasındaki ilişki incelenmiştir. Araştırma alt sosyoekonomik düzeyde beş yaş grubundaki 181 çocuk ve onlara eğitim veren 21 okul öncesi öğretmeni ile gerçekleştirilmiştir. Çocukların alııı ve ifade edici dil sözcük bilgisi düzeylerini belirlemek için TiFALDi; alıcı ve ifade edici dil gelişimi düzeylerini belirlemek için ise TEDiL ölçekleri kullanılmıştır. Öğretmenlerin kitap okuma etkinliklerini değerlendirmek için araştırmacı tarafından Kitap Okuma Etkinliği Öğretmen Değerlendirme Formu (KOD) geliştirilmiş; kitap merkezinde yer alan ve etkinlik sırasında okunan resimli öykü kitaplarını değerlendirmek için Resimli Öykü Kitaplarını Değerlendirme Ölçeği kullanıımıştır. Araştırmanın sonuçlarına göre resimli öykü kitaplarının niteliği ve kitap okuma etkinliklerinde alıcı dili destekleme, ifade edici dili destekleme ve etkinlik ortamı niteliği ile çocukların alıcı ve ifade edici dil sözcük bilgileri ve dil gelişimleri arasında istatistiksel açıdan anlamlı ve pozitif bir ilişki bulunmuştur. Öykünün etkili okunmasının niteliği ile alıcı ve ifade edici sözcük bilgisi ve dil gelişimi arasında ise istatistiksel olarak anlamlı ilişki bulunamamıştır. Beş yaş çocuklarının sözel dil performansını anlamlı olarak yordayan değişkenlerin sırasıyla ailenin aylık geliri, ailenin çocuğa kitap okuma sıklığı, çocuğun alıcı dil sözcük bilgisi, çocuğun ifade edici dil sözcük bilgisi ile öğretmenin ifade edici dili destekleme puanları olduğu sonucuna ulaşılmıştır.

Anahtar Kelimeler: Okul öncesi eğitim, kitap okuma etkinlikleri, alıcı dil gelişimi, ifade edici dil gelişimi, sözcük bilgisi, resimli öykü kitapları
\end{abstract}

\section{The Relationship between the Quality of Book Reading Activities and Picture Books and the Language Development of Socioeconomically Disadvantaged Children}

\section{Abstract}

This study examines the relationship between the quality of read-aloud activities and picture books and the receptive and expressive vocabulary and language development of preschool children of lower socioeconomic status. The study was conducted with 181 children aged five years and 21 preschool teachers. The TIFALDI scale was used to determine the children's receptive and expressive vocabulary, and the TEDIL scale was used to investigate their receptive and expressive language development. The Read-Aloud Teacher Assessment Form was developed by the researcher in this study to assess the read-aloud activities, and the Picture Book Assessment Scale was used to assess picture books read during the activity and in the book center. The findings showed that there was a statistically significant and positive correlation between the quality of the teacher's support for the children and providing an appropriate educational environment in the

\footnotetext{
*Bu çalışma birinci yazarın doktora tezinden üretilmiştir.

**Arş. Gör. Dr., Hacettepe Üniversitesi, Eğitim Fakültesi, Temel Eğitim Bölümü, Ankara, ayseguldeniz@hacettepe.edu.tr, ORCID: orcid.org/0000-0003-0644-2902

${ }^{* * *}$ Prof. Dr., Hacettepe Üniversitesi, Eğitim Fakültesi, Temel Eğitim Bölümü, Ankara, mgonen@hacettepe.edu.tr, ORCID: orcid.org/0000-0002-5190-1170
} 
read-aloud activities and the quality of the picture books and the receptive and expressive vocabulary and language development. No statistically significant relation was found between the quality of reading stories effectively and receptive and expressive vocabulary and language development. It was concluded that the variables predicting 5 -year-old children's spoken language performance were family monthly income, family frequency of reading books aloud, children's receptive and expressive vocabulary, and teachers' points to support children's expressive language.

Keywords: Preschool education, book reading activities, receptive language development, expressive language development, vocabulary, picture books

\section{Giriş}

Erken çocukluk yıllarını içine alan okul öncesi dönem, çocuğun doğduğu günden ilkokul eğitimine başladığı güne kadar süren ve bireylerin yaşamlarında önemli rol oynayan becerilerin kazanıldığı bir dönem olarak karşımıza çıkmaktadır. Bu dönem, özellikle dil becerilerinin gelişimi açısından kritik yıllar olarak değerlendirilmektedir. Dil gelişimini etkileyen pek çok faktör bulunmakla birlikte sosyoekonomik düzeyin dil gelişimi üzerindeki etkisi yapılan araştırmalarda ortaya koyulmuştur. Alt sosyoekonomik düzeydeki çocukların dil gelişimlerinin, orta ve üst sosyoekonomik düzeydeki çocukların dil gelişimlerine göre daha düşük düzeyde olduğu görülmektedir (Kandır ve Koçak Tümer, 2013; Kandır ve Orçan, 2009; Walker, Greenwood, Hart ve Carta, 1994). Alt sosyoekonomik düzeydeki çocukların, orta ve üst sosyoekonomik düzeydeki çocuklara göre dil gelişimi açısından anaokuluna daha geride başladığına (Lee ve Burkham, 2002) ve akademik beceriler açısından da risk altında olduklarına (Biemiller, 2006; Hart ve Risley, 1995, 2003) dair araştırmalar bulunmaktadır. Sözcük bilgisi zayıf olan çocuklar okula başladıklarında okumada ciddi güçlüklerle karşılaşabilmektedir (Ergin, 2020). Bu nedenle okul öncesi eğitim çağında özellikle alt sosyoekonomik düzeydeki çocukların dil gelişimi ile ilgili becerilerinin desteklenmesi oldukça önemli bir konu olarak karşımıza çıkmaktadır.

Çocuklara kitap okumanın dil gelişimi açısından yararlı olduğunu gösteren, ebeveynlerin çocuklarıyla birlikte kitap okurken kullandıkları zengin dil ile çocukların dil gelişimi arasında anlamlı bir ilişki olduğunu ortaya çıkaran çalışmalar olduğu görülmektedir (Bus ve Van IJzendoorn, 1995; DeBaryshe, 1993; Mol, Bus, De Jong ve Smeets, 2008; Payne, Whitehurst ve Angell, 1994; Van Kleeck, Gillam, Hamilton ve McGrath, 1997). Tabors, Snow ve Dickinson (2001), hem ev hem de sinıf ortamlarının çocukların dil gelişimine katkıda bulunacağını belirtmektedir. Bununla birlikte ilkokula başlarken kritik olan dil gelişimi ile ilgili becerilerinin desteklenmesinde nitelikli sınıf ortamlarının, çocukların ihtiyaç duydukları deneyimleri sağlayabileceğini dile getirmektedir.

Öğretmenlerin de ebeveynler gibi çocukların dil gelişimi için önemli modeller olduğu ve okul öncesi eğitimde çocukların dil becerilerini destekleyen en önemli etkinliklerin kitap okuma etkinlikleri olduğu belirtilmektedir (National Early Literacy Panel [NELP], 2008). The International Reading Association (IRA) ve The National Association for the Education of Young Children (NAEYC) kuruluşlarının ortak olarak hazırladıkları belgede, kitap okuma etkinlikleri "Çocukların okuma becerilerini kazanmaları açısından en gerekli etkinlik" olarak değerlendirilmektedir (IRA ve NAEYC, 1998). Kapsamlı bir dilin kullanımı ve sözcük bilgisi ile ilgili bilişsel açıdan destekleyici konuşmalar, diğer etkinliklere kıyasla en fazla kitap okuma etkinlikleri sırasında gerçekleşmektedir (Gest, Holland Coviello, Welsh, Eicher Catt ve Gill, 2006). Yapılan çalışmalar, okul öncesi eğitimde zengin bir dilin kullanıldığı kitap okuma etkinliklerinin çocukların dil gelişimine katkıda bulunduğunu ortaya koymaktadır (Dickinson ve diğ., 2003; Dickinson ve Tabors, 2001). Etkileşimlerin arttırılması ve eğitim ortamının sözel olarak zenginleştirilmesi, çocukların sözcük gelişimlerini olumlu olarak etkilemektedir (Dickinson, Cote ve Smith, 1993; Rush, 1999). Daha fazla sözcük duyan çocuklar daha fazla sözcük öğrenmekte ve sözcük dağarcıkları büyüdükçe yeni sözcükleri öğrenmeleri daha kolay olmaktadır (De Temple ve Snow, 2003).

Sosyal etkileşimci bir perspektiften bakıldığında çocuklar dili, sözcük, dil bilgisi ve dilin kullanımı ile ilgili kendilerine model olan öğretmenleriyle girdikleri sosyal etkileşimler yoluyla edinmektedirler (Chapman, 2000). Sözel iletişimde bulunabilen ve kendisine kitap okunan çocukların, okuma becerileri konusunda diğer çocuklara göre daha ileride bir düzeyde oldukları görülmektedir (Yazgan İnanç, Bilgin 
ve Kılıç Atıcı, 2020). Kitap okuma deneyimine sahip olan çocuklar, konuşma dili ile yazılı dili birbirinden ayırt etmeyi öğrenmekte ve bu deneyimler çocukların yazılı dili daha iyi anlamalarına yardımcı olmaktadır (Neuman ve Roskos, 1998). Kitap okuma etkinlikleri ile çocukların sözcük ve kavram bilgileri artmakta ve bu etkinlikler okuma becerisinin temellerini oluşturmaktadır. Çocuklar kitap okuma etkinlikleri aracılığıyla dünya hakkında daha fazla bilgi edinmekte, yazılı dili öğrenmekte ve ses ve yazı farkındalığı becerilerini kazanmaktadır. Buna ek olarak çocukların farklı metin yapılarına aşinalıkları artmaktadır (Armbruster, Lehr ve Osborn, 2006; Diamant Cohen ve Hetrick, 2013; Yavuzer, 2018). Risk altında, özel gereksinimli, alt sosyoekonomik düzeyde ya da farklı kültürel çevreye sahip olan çocuklar kitap okuma deneyimine en fazla ihtiyacı olan çocuklar olarak görülmektedir. Dili daha üst bir seviyede kullanabilmeleri için bu çocuklarla çok sayıda kitap okuma etkinliği gerçekleştirilmesi gerekmektedir (Svensson, 2009).

Temelde dil, alıcı dil ve ifade edici dil olmak üzere iki tipe sahiptir. Alıcı dil söyleneni anlama yeteneğini anlatırken; ifade edici dil ise konuşulan dilin bilgisi ve kullanımı ile iletişim kurabilme yeteneği olarak tanımlanmaktadır. Alıcı dil becerileri; dinleme, anlama ve ifade etme yeteneğini içeren konuşma ve iletişim kurma becerilerinden daha erken gelişmektedir. Küçük yaşlarda çocuklar, kullandıklarından daha fazla kelimeyi ve daha gelişmiş cümle yapılarını anlamaktadır (Bredekamp, 2015: 377). Dil gelişimi ile ilgili beceriler, çocukların ileriki dönemlerdeki okuma ve akademik başarılarının temelini oluşturmaktadır. Yapılan çok sayıda çalışmada, dil ve erken okuryazarlık becerilerinin çocukların sonraki eğitim kademelerinde sahip oldukları okuma performanslarının ve akademik başarılarının bir yordayıcısı olduğu belirlenmiştir (Catts, Fey, Zhang ve Tomblin, 2001; Hart ve Risley, 2003; Scarborough, 2001; Sénéchal, LeFevre, Thomas ve Daley, 1998; Storch ve Whitehurst, 2002). Okul, dezavantajlı bölgede yaşayan çocuklar için en önemli öğrenme pratiklerinin sağlandığı yer olarak değerlendirilmektedir. Özellikle okul öncesi dönemde, çevresel faktörlerden dolayı çocukların gelişimleri üzerinde etkili olan dezavantajlı durumların, okul ortamında öğretmenler tarafından sağlanan uygun koşullarla azaltılabileceği düşünülmektedir.

İyi planlanmış bir kitap okuma etkinliği, tahmin yürütme, açık uçlu sorular sorma, çocukların yaşantılarıyla ve deneyimleriyle bağlantı kurma, karakterlerle ve diğer kitaplarla da bağlantı kurmayı gerektiren sorular sorma gibi uygulamaları içerir. Bu uygulamalara dikkat edilerek okunan kitaplar çocukların anlam geliştirmesine ve üretmesine yardımcı olmakta; kendilerini ifade etmelerine olanak sağlamaktadır (Pressley ve Hilden, 2002). Fisher, Flood ve Lappand Frey (2004), çocuklar açısından ilgi çekici kitaplar seçmenin ve kitap okuma etkinliğinin öncesinde ve sonrasında çocukları tartışmaya teşvik etmenin, kitap okuma açısından etkili stratejiler olduğunu belirtmektedir. Çocukların yaşları büyüdükçe, resimli öykü kitaplarında dil ve kavram yönünden daha gelişmiş ve detaylı metinler yer almaktadır (Gönen, 2013). Çocuğun konuşma dilinde duyduğu ve uyguladığı söz dizimsel yapıları ve dilbilgisine ait kuralları kitaplardaki metinler aracılığıyla tekrar duyması, dilin yapısına olan aşinalığını arttırmakta; dil gelişimi bu şekilde desteklenmektedir. Çocuklara yönelik öykü kitapları, dil gelişimi açısından çocukların duymaları gereken bir zenginliğe sahip olmalı; bu özellikler açısından nitelikli kitapların seçilmesi gerekmektedir (Barnes, Grifenhagen ve Dickinson, 2016; Tüfekçi Can, 2014).

Resimli öykü kitaplarının içerik ve resimleme özellikleri açısından taşımaları gereken bazı özellikler bulunmaktadır. Çocuklara yönelik yazılan bu eserlerde, temanın açık ve seçik olması gerekmektedir (Oğuzkan, 2013). Ele alınan konuların, 2-7 yaş gelişim düzeyindeki çocuklar için açık ve anlaşılır olması önem taşımaktadır. Konuların, çocukların gerçek hayatlarından ve yakın çevrelerindeki olay ve olgular arasından seçilmesi ve çocuklar açısından mizah duygusunu içeren eğlendirici ve dinlendirici nitelikte konulara yer verilmesi önerilmektedir (Gönen, 2013; Karatay, 2011; Oğuzkan, 2013; Sever, 2008). Karakterlerin fiziksel ve ruhsal özellikler açısından abartısız ve inandırıcılık düzeyi yüksek olması (Sever, 2008), zamanın doğrusal olarak ilerlemesi ve olaylardaki çatışmaların düğüm noktasına ulaştıktan sonra hemen çözüme ulaşması gerekmektedir (Karatay, 2011). Yapmacık, zevksiz, bayağı ve çocuklara uygun olmayan bir anlatım biçiminden, eski ve anlaşııması güç sözcüklerin kullanımından kaçınılması önerilmektedir (Oğuzkan, 2013). Hem çocuğun seviyesinin üzerinde kavramakta zorlanacağı uzun cümleler hem de seviyesinin altında olan kısa ve basit cümleler kitaba karşı olan ilgiyi azaltması sebebiyle cümle uzunluklarında gelişim özelliklerinin dikkate alınması gerekmektedir (Karatay, 2011). Kitapların çocukların düşünme becerilerini geliştirmesi, farklı kültürlere 
saygııı olması ve korkutucu öğelere yer vermemesi beklenmektedir. (Mac Naughton ve Williams, 2009). Resimlemede özensiz ve tek düze resimler kullanılmamalı; nitelikli bir resimleme için çizerin metni iyi anlaması, mekânı ve tipleri bu anlam doğrultusunda oluşturması gerekmektedir (Bassa, 2013; Hancock, 2007). Resimlemelerin öyküyü yansıtacak güçte olmasına ve resmin ait olduğu metnin yanında yer almasına dikkat edilmesi gerektiği belirtilmektedir (Bassa, 2103; Gönen, 2013; Lynch Brown, Tomlinson ve Short, 2011).

İlgili alan yazın incelendiğinde kitap okuma etkinlikleri ile çocukların dil gelişimi ve erken okuryazarlık becerileri arasındaki ilişkiyi inceleyen araştırmalar karşımıza çıkmaktadır (Beals, De Temple ve Dickinson, 1994; Connor, Morison ve Slomonski, 2006; Hindman, Wasik ve Erhart, 2012; Lipsky, 2011; Mascareño, Snow, Deunk ve Bosker, 2016; Tepetaş Cengiz, 2015). Bu çalışmalarda dil gelişimi açısından daha çok alıcı dil sözcük bilgisi üzerine yoğunlaşıldığı görülmektedir.

36-72 aylık çocuklar için hazırlanan MEB Okul Öncesi Eğitimi Program Kitabı'nda (2013), dil gelişimine yönelik 12 kazanım ve 73 gösterge bulunmakta ve dil gelişiminde en önemli etkinlik olarak Türkçe etkinliklerine işaret edilmektedir. Türkçe etkinliklerini planlarken öğretmenlerin çocukların yaş ve gelişim özelliklerini dikkate almaları, farklı yöntem ve teknikleri kullanmaları, sosyal ve kültürel olarak dezavantajlı çocukları göz önünde bulundurmaları gerektiği belirtilmektedir. Okul öncesi eğitimin temel amaçlarından birisinin de şartları elverişsiz çevrelerden ve ailelerden gelen çocuklar için ortak bir yetiştirme ortamı yaratmak olduğu görülmektedir (MEB, 2013). Bu noktada dezavantajı çevrelerde okul öncesi eğitim alan çocukların dil gelişiminin desteklenmesinin daha da önem kazandığı görülmektedir.

\section{Araştırmanın Amacı ve Önemi}

Bu araştırmada, resimli öykü kitaplarının ve okul öncesi öğretmenleri tarafından uygulanan kitap okuma etkinliklerinin niteliği ile alt sosyoekonomik düzeydeki ailelerden gelen beş yaş grubundaki çocukların, alıcı ve ifade edici dil sözcük bilgileri ve dil gelişimleri arasında anlamlı bir ilişki olup olmadığının incelenmesi amaçlanmaktadır.

Ülkemizde okul öncesi eğitimin amaçlarının arasında şartları elverişsiz çevrelerden ve ailelerden gelen çocuklar için ortak bir yetiştirme ortamı yaratmak ve çocukların Türkçeyi doğru ve güzel konuşmalarını sağlamak yer almaktadır (MEB, 2013). Okul öncesi eğitimde özellikle alt sosyoekonomik düzeyde yer alan çocukların eğitimine öncelik verilmesi ile Türkçenin doğru ve düzgün konuşulmasının amaçlanması, bu araştırmanın amacıyla birebir örtüşmektedir. Öte yandan resimli öykü kitapları aracılığıyla çocukların bilişsel, duyuşsal, sosyal ve dil gelişimi desteklenebilmektedir. Resimli öykü kitaplarının çocukların gelişim alanlarını destekleyebilmesi için fiziksel, içerik ve resimleme özellikleri açısından iyi bir nitelik taşıması gerekmektedir. Bu nedenle eğitim ortamında bulunan ve öğretmenler tarafından çocuklara okunan öykü kitaplarını iyi niteliğe sahip kitaplar arasından seçilmesi önemli bir konu olarak karşımıza çıkmaktadır. Alan yazın incelendiğinde resimli kitapların niteliğini değerlendirmeye yönelik geçerliği ve güvenirliği yapılmış bir ölçme aracının bulunmadığı görülmüştür. Resimli öykü kitaplarının niteliğini belirlemeye yönelik bir ölçeğin geliştirilmesinin araştırmacılar, öğretmenler, ebeveynler ve yayıncılar açısından yararlı olacağı düşünülmektedir. Bu ölçme aracının yanı sıra araştırma kapsamında MEB Okul Öncesi (2013) Programı́na uygun olarak öğretmenlerin Türkçe etkinlikleri kapsamında gerçekleştirdikleri kitap okuma etkinliklerindeki uygulamalarının değerlendirildiği bir rubrik geliştirilmesi ile de ilgili alan yazına katkı sunulmaya çalışılmıştır.

Ülkemizde okul öncesi eğitim sınıflarında gerçekleştirilen kitap okuma etkinlikleri ile ilgili yeterince araştırma yapılmadığı görülmektedir. Bu konunun özellikle de alt sosyoekonomik düzeydeki ailelerin çocuklarının devam ettiği okul öncesi eğitim kurumları açısından ele alınmamış olduğu göze çarpmaktadır. Ayrıca alan yazında dil gelişimi ile ilgili daha önce yapılan çoğu çalışmada, çocukların alıcı dil sözcük bilgilerinin incelendiği görülmektedir. Bu çalışmada çocukların alıcı dil sözcük bilgilerinin yanı sıra ifade edici dil sözcük bilgileri ile alııı ve ifade edici dil gelişimleri de incelenmektedir.

Kitap okuma etkinliklerinin ve resimli öykü kitaplarının niteliği ile okul öncesi eğitime devam eden alt sosyoekonomik düzeydeki beş yaş çocukların alıcı ve ifade edici dil sözcük bilgileri ve dil gelişimleri arasında anlamlı bir ilişki olup olmadığının incelenmesinin amaçlandığı bu çalışmada aşağıdaki sorulara yanıt aranmıştır: 
Kitap Okuma Etkinliklerinin ve Resimli Öykü Kitaplarının Niteliği ile Sosyoekonomik Açıdan Dezavantajlı Çocukların Dil Gelişimleri Arasındaki ilişki

1. Kitap okuma etkinliklerinin ve resimli öykü kitaplarının niteliği ile beş yaşındaki çocukların alıcı dil sözcük bilgileri arasında anlamlı bir ilişki var mıdır?

2. Kitap okuma etkinliklerinin ve resimli öykü kitaplarının niteliği ile beş yaşındaki çocukların alıcı dil gelişimleri arasında anlamlı bir ilişki var mıdır?

3. Kitap okuma etkinliklerinin ve resimli öykü kitaplarının niteliği ile beş yaşındaki çocukların ifade edici dil sözcük bilgileri arasında anlamlı bir ilişki var mıdır?

4. Kitap okuma etkinliklerinin ve resimli öykü kitaplarının niteliği ile beş yaşındaki çocukların ifade edici dil gelişimleri arasında anlamlı bir ilişki var mıdır?

5. Kitap okuma etkinliklerinin ve resimli öykü kitaplarının niteliği ile beş yaşındaki çocukların sözel dil performansları arasında anlamlı bir ilişki var mıdır?

6. Beş yaş çocuklarının sözel dil performansını hangi değişkenler anlamlı düzeyde açıklamaktadır?

\section{Araştırmanın Modeli}

\section{Yöntem}

Okul öncesi eğitimde öğretmenler tarafından büyük grup etkinliği olarak gerçekleştirilen kitap okuma etkinliklerinin ve eğitim ortamındaki resimli öykü kitaplarının niteliği ile okul öncesi eğitime devam eden alt sosyoekonomik düzeydeki beş yaş çocuklarının dil gelişimleri arasındaki ilişkinin incelenmesini amaçlayan bu araştırma, nicel araştırma yöntemlerinden ilişkisel tarama modeli ile yapılmıştır. iliş̧kisel tarama modelinde değişkenler arasında birlikte değişimin varlı̆̆ının veya derecesinin belirlenmesi amaçlanmaktadır. Tarama yolu ile belirlenen ilişkiler değişkenler arasındaki neden-sonuç ilişkisini değil; bir değişkendeki değişimi belirleyerek diğerini tahmin etmeyi sağlamaktadır (Karasar, 2020).

\section{Örneklem / Araştırma grubu}

Bu araştırmanın evreni Ankara ilinde Millî Eğitim Bakanlığına bağlı anaokulu ve anasınıflarına devam eden alt sosyoekonomik düzeydeki beş yaş grubu çocuklarından oluşmaktadır. Araştırmada alt sosyoekonomik düzeydeki çocuklara yer verilmesi amaçlandığından örneklem hızla göç alan, nüfus yoğunluğu fazla olan, gecekondu alanları bulunan ve dezavantajlı bölge kategorisine giren Altındağ ilçesinden seçilmiştir. Ayrıca 2012 yılında Hacettepe Üniversitesi ile Altındağ İlçe Milli Eğitim Müdürlüğü arasında Eğitimde İş Birliği Protokolü'nün imzalanmış olması da örneklem grubunun Altındağ ilçesinden seçilmesinde etkili olmuştur. Altındağ ilçesinde bağımsız anaokulları ve ilkokula bağlı anasınıflarında görev yapan 21 okul öncesi öğretmeni ile beş yaş grubundaki (60-71 aylık) 92'si kız, 89'u oğlan toplam 181 çocuk bu araştırmanın örneklemini oluşturmaktadır. Örneklem Altındağ ilçesinde eğitim veren okul öncesi öğretmenleri arasından rast gele seçilmiş ve bu öğretmenlerin eğitim verdiği çocuklardan çalışmada yer alacak çocukların belirlenebilmesi amacıyla ailelerden veli demografik bilgi formunu doldurmaları istenmiştir. Ekonomik düzeyin, Tüik (2016) tarafından belirlenen yoksulluk sınırının altında (4.826 TL'den az) olması, anne ve babanın eğitim düzeyinin düşük olması ölçütleri belirlenerek; her sınıfta bu ölçütlere uyan 8-12 arasında alt sosyoekonomik düzeydeki çocuk çalışmada yer almıştır.

\section{Veri Toplama Araçları}

Araştırmada çocukların alıcı ve ifade edici sözcük bilgilerini değerlendirmek amacıyla TiFALDi; alıcı ve ifade edici dil gelişimlerini değerlendirmek amacıyla da TEDí kullanılmıştır. Resimli öykü kitapları "Resimli Öykü Kitaplarını Değerlendirme Ölçeği” ile kitap okuma etkinlikleri ise "Kitap Okuma Etkinliği Öğretmen Değerlendirme Formu" ile değerlendirilmiştir. Bunların yanı sıra demografik veriler öğretmenler için Öğretmen Demografik Bilgi Formu, veliler için Veli Demografik Bilgi Formu aracılığı ile toplanmıştır.

Resimli öykü kitaplarını değerlendirme ölçeği. Kitap okuma etkinliğinde kullanılan ve kitap merkezinde bulunan resimli öykü kitaplarının niteliğini belirlemek için Deniz ve Gönen (2020) tarafından geliştirilen Resimli Öykü Kitaplarını Değerlendirme Ölçeği kullanılmıştır. Resimli Öykü Kitaplarını Değerlendirme Ölçeği, resimli öykü kitaplarını resimleme ve içerik özellikleri açısından 
değerlendirmek amacıyla oluşturulmuştur. Ölçeğin geliştirilmesi sürecinde alan yazın incelenmiş ve resimli öykü kitaplarının sahip olması gereken özellikler kapsamında maddeler belirlenerek 7 alan uzmanının görüşüne sunulmuştur. Ölçek, üçlü Likert tipinde geliştirilmiş olup yetersiz (1), kısmen yeterli (2), yeterli (3) şeklinde derecelendirilmiştir. Ölçeğin geçerlik ve güvenirlik çalışması tesadüfi örnekleme yöntemi ile seçilen 200 kitap ile gerçekleştirilmiştir. Geçerlik ve güvenirlik çalışmaları sonucunda, ölçeğin tek boyuttan ve 21 maddeden oluştuğu belirlenmiştir. Ölçeğin varyansa yaptığı katkının \%48.927 olduğu ortaya çıkmıştır. Madde faktör yükleri .414 ile .869 arasında değişmektedir. Ölçekte yer alan maddelerin, madde toplam korelasyon katsayıları ise .379 ile .832 arasında değişmektedir. Cronbach alfa katsayısı .94 olarak elde edilmiştir. Elde edilen bu sonuç .90 'dan büyük olduğu için ölçek, güvenirliği yüksek bir ölçme aracı olarak kabul edebilir (George ve Mallery, 2003; Özdamar, 2002). Geçerlik ve güvenirlik çalışmaları kapsamında seçilen 200 kitaptan 30'u farklı bir okul öncesi eğitimi alanı uzmanı tarafından değerlendirilmiş ve puanlayıcı güvenirliği hesaplanmıştır. íki puanlayıcı arasındaki korelasyon katsayısı .92 olarak bulunmuştur. Yapılan analizler sonucunda Resimli Öykü Kitaplarını Değerlendirme Ölçeği'nin resimli öykü kitapların niteliğini belirlemek açısından geçerli ve güvenilir bir araç olduğunu destekleyen verilere ulaşılmıştır. Son haliyle tek boyuttan ve 21 maddeden oluşan ölçekten alınabilecek en düşük puan 21 iken, en yüksek puan ise 63'tür. Ölçekten alınan puanların düşük olması resimli öykü kitabının niteliğinin yetersiz olduğunu belirtirken, yüksek puan alınması öykü kitabının niteliğinin yüksek olduğunu belirtmektedir.

Kitap okuma etkinliği öğretmen değerlendirme formu (KOD). Kitap Okuma Etkinliği Öğretmen Değerlendirme Formu (KOD), okul öncesi öğretmenlerinin resimli öykü kitabı okuma çalışmalarında, çocukların dil gelişimlerini olumlu yönde etkileyecek davranışları hangi düzeyde gerçekleştirdiklerini ortaya çıkarmak amacıyla geliştirilmiştir. Geliştirilen ölçme aracındaki maddeler, ilgili alan yazın ile öğretmenlerin ve ebeveynlerin öykü okumalarını değerlendirmek için geliştirilen ölçme araçları Teacher Behaviour Rating Scale (TBRS) (Landry, Crawford, Gunnewig ve Swank, 2001), Assessing Adult/Child Storybook Reading Practices (ACIRI) (DeBruin Parecki, 1999), The Book Reading Assessment Scoring System (BRASS) (Justice, Sutton, Sofka, McGinty ve Pianta, 2005), Observation Measures Of Language And Literacy Instruction (OMLiT-RAPT) (Goodson, Layzer, Smith ve Rimdzius, 2006), Systematic Assessment of Book Reading (SABR) (Justice, Zucker ve Sofka, 2010), Etkileşimli Kitap Okuma Davranışları Kontrol Listesi (Ergül, Akoğlu, Sarıca, Tufan ve Karaman, 2015) ve Yapılandırılmış Gözlem Formu (Işıkoğlu Erdoğan ve diğ., 2016) incelenerek belirlenmiştir. Ayrıca video kaydına alınan kitap okuma etkinliklerinde öğretmenlerin gerçekleştirdikleri davranışlar da incelenerek maddelerin belirlenmesinde göz önünde bulundurulmuştur. Maddelerin MEB 2013 Okul Öncesi Eğitim Programı́na da uygun olması da amaçlanmıştır.

Değerlendirme formu rubrik olarak geliştirilmiş; öğretmenlerin performanslarına ilişkin yetersiz (1), kısmen yeterli (2) ve yeterli (3) olmak üzere ölçütler belirlenerek bir puanlama yönergesi oluşturulmuştur. Video kaydına alınan kitap okuma etkinlikleri bu form aracılı̆̆ıyla değerlendirilmiştir. Değerlendirme aracının kapsam ve yapı geçerliliği için iki ölçme ve değerlendirme uzmanı, dört alan uzmanı, bir dil uzmanı olmak üzere toplam yedi uzmanın görüşüne başvurulmuştur. Araştırmada yer alan öğretmenlerin dışındaki iki öğretmenin video kaydına alınan kitap okuma etkinliği ile pilot çalışma yapılmış ve ölçme aracındaki maddelere son hali verilmiştir. KOD ölçme aracı için puanlayıcılar arasındaki uyumu belirlemek için Spearman Korelasyon Katsayıları hesaplanmıştır. Birinci ve ikinci puanlayıcı arasındaki korelasyon katsayılarının öyküyü etkili okuma boyutunda .988, alıcı dili destekleme boyutunda .958 , ifade edici dili destekleme boyutunda .991 ve etkinlik ortamı boyutunda .982 olduğu görülmektedir. İki puanlayıcı arasında dört alt boyutta da 0.01 anlamlılık düzeyinde olumlu ve yüksek korelasyon bulunmuştur. Değerlendirme Formu A) Öyküyü Etkili Okuma (5 madde), B) Alıcı Dili Destekleme (10 madde), C) ifade Edici Dili Destekleme (10 madde) ve D) Etkinlik Ortamı (4 madde) olmak üzere toplam dört alt boyuttan ve 29 maddeden oluşmaktadır. Öyküyü Etkili Okuma, öğretmenin öyküyü okurken uygun bir hızda okumasını, ses tonunu doğru kullanmasını, vurgu ve tonlamalara dikkat etmesini, jest ve mimiklere önem vermesini ve karakterler için ses değişikliği yapmasını içeren maddelerden oluşmaktadır. Alıcı Dili Destekleme boyutundaki maddeler, öykü kitabını tanıtma, öyküyü ayrıntılandırma, sözcüklerin anlamlarını açıklama ve dili kullanmada model olma kapsamında belirlenmiştir. Ifade Edici Dili Destekleme boyutunda, öykü kitabını tanıtma, öykü kapsamında sorular 
sorma ve dili kullanmaya teşvik etme ile ilgili maddeler ele alınmıştır. Etkinlik ortamı boyutu, kitap okuma etkinliğinin nasıl bir sınıf ikliminde gerçekleştirildiğinin belirlenmesini amaçlayan maddelerden oluşmaktadır. Bu alt boyutta çocukların kitap okuma etkinliği için rahat bir şekilde yerleşmeleri, öğretmenin etkinlik boyunca çocuklarla etkili bir şekilde iletişim kurması ve çocuklara olumlu geribildirimler vermesi ölçütleri kapsamında belirlenmiştir.

Rubrikten elde edilen puanların yüksek olması öğretmenin çocukların dil gelişimini destekleyecek olumlu davranışları iyi ve yeterli düzeyde gerçekleştirdiğini, puanların düşük olması ise öğretmenin çocukların dil gelişimini destekleme davranışlarını gerçekleştirme düzeyinin kısmen yeterli ya da yetersiz olduğu şeklinde değerlendirilmektedir. Etkili Okuma alt boyutunda ölçme aracından alınabilecek en düşük puan 5 , en yüksek puan ise $15^{\prime}$ tir. Alıcı dili destekleme ve ifade edici dili destekleme alt boyutları için alınabilecek en düşük puan 10, en yüksek puan ise 30 'dur. Etkinlik ortamı alt boyutundan alınabilecek en düşük puan 4 , en yüksek puan ise 12 'dir.

TiFALDi. Türkçe ifade Edici ve Alıcı Dil Kelime Testi (TiFALDi) Berüment ve Güven (2010) tarafından geliştirilmiştir. Bu test 2-12 yaş çocuklara yönelik olarak hazırlanmış olan bir kelime testidir. Alıcı dil kelime alt testinde çocuklara göstermek için her sayfada dört tane resim bulunmaktadır. Yetişkinin söylediği sözcüğün hangi resme ait olduğunu çocuğun parmağıyla göstermesi istenmektedir. ifade edici dil alt testinde her sayfada bir sözcüğün resmi bulunmaktadır. Çocuktan resimde gördüğünün ne olduğunu söylemesi istenir. Alıcı dil alt testi 104 maddeden oluşmakta olup test-tekrar test güvenirliği .97 olarak bulunmuştur ( $p<.01)$. 104 maddenin iç tutarlılık katsayısı Cronbach Alpha= .99 olarak bulunmuştur. Yarıya bölme analizleri ile elde edilen tüm örneklem için Spearman-Brown değeri .99 olarak bulunmuştur. ifade edici dil kelime alt testinde ise toplam 80 madde bulunmaktadır. Test-tekrar test güvenirliği .97 olarak bulunmuştur $(p<.01) .80$ maddenin iç tutarlılık katsayısı Cronbach Alpha = .98 olarak bulunmuştur. Yarıya bölme analizleri ile elde edilen tüm örneklem için SpearmanBrown değeri .99 olarak elde edilmiştir. Alıcı dil alt testinin uygulamasında çocuğun arka arkaya 8 doğru cevabının olduğu yer taban puan olarak kabul edilmektedir. Test arka arkaya gelen madde aralığında 8 yanlış cevaptan sonra bitirilir. İfade edici dil kısmında ise yine çocuğun arka arkaya 8 doğru cevabının olduğu yer taban puan olarak kabul edilmekte, test arka arkaya gelen 8 madde aralığında 6 yanlıştan sonra bitirilmektedir. Testlerden elde edilen ham puanlar çocuğun yaş dilimine göre standart puana çevrilir. Ölçeğin eğitimi ve uygulama izni araştırmacı tarafından alınmıştır.

TEDiL. TEDIL, Test of Early Language Development (TELD-3) dil gelişim testinin Türkçeye uyarlamasıdır. 2007 yılında testin madde analizleri, geçerlik ve güvenirlik çalışması tamamlanmış ve 2009 yılında norm çalışmalarına başlanmıştır (Topbaş ve Güven, 2011). Test, bireysel olarak yönetilen, norm referanslı ve 2 yaş 0 ay ve 7 yaş 11 ay arasındaki çocukların alıcı ve ifade edici dil becerilerini ölçmeyi amaçlayan bir testtir. Test sonuçları erken dönemde dil bozukluğu olan çocukları tanılayabilme, dil gelişimlerinin zayıf ve güçlü yanlarını gösterme, gelişim sürecine dair bilgi verme ve araştırma yapma gibi amaçlarla kullanılabilmektedir.

Testin standardizasyon çalışmalarında Türkiye'nin yedi coğrafi bölgesinden seçilen otuz üç ilde yaşayan 1627 çocuk yer almıştır. TEDiL'in güvenirlik çalışmasında, alfa iç turtalıık katsayıları, farklı yaş grupları ve farklı demografik alt gruplarda her iki form ve alt testler için .86 ile .98 arasında bulunmuştur. Test-tekrar test yöntemi sonucunda korelasyon katsayıları A formu için Alıcı Dil .96 ve ifade Edici Dil .89 olarak bulunmuştur. Uygulayıcılar arası her iki formu ve alt testleri puanlamada \%100 bir uyuşma ve .99 korelasyon katsayısı bulunmuştur. TEDiL'in yapı geçerliği için yapılan analizlerde, Alıcı Dil ve ifade Edici Dil alt testleri için korelasyon katsayısının .87 ile .91 arasında olduğu görülmüştür (Topbaş ve Güven, 2011).

TEDiL A ve B olmak üzere paralel formlardan oluşmaktadır. Her bir form Alıcı ve ifade Edici Dil olmak üzere iki alt testi içermektedir. Bu alt testler dilin anlambilgisi, biçimbilgisi ve sözdizimi alanlarını ölçen maddelerden oluşmuştur. Her bir formda toplam 76 madde bulunmaktadır. Bu çalışmada Türkçe Erken Dil Gelişim Testi (TEDiL) A formu uygulanmıştır.

A formu Alıcı Dil alt testinde 24 anlambilgisini ve 13 sözdizimi/biçimbilgisini ölçen madde ve ifade Edici Dil alt testinde 22 anlambilgisini, 17 sözdizimi/biçimbilgisini ölçen madde bulunmaktadır. Bu maddelerin bir kısmında resim gösterme veya betimleme diğer bir kısmında ise sözel yönergeleri yerine getirme ve sorulara sözel olarak yanıt verme işlenmektedir. Bu ölçeğin alıcı ve ifade edici dil gelişiminin 
toplam puanı sözel dil performansını oluşturmaktadır (Topbaş ve Güven, 2011). Testin uygulanmasında hem alıcı dil hem de ifade edici dil kısmında taban oluşturabilmek için çocuğun üst üste üç tane soruyu doğru yanıtlaması gerekmektedir. Çocuk, arka arkaya üç yanlış yaptığında ise teste son verilir. Testin sonunda alıcı ve ifade edici dil alt testlerinden alınan ham puanlar standart puana çevrilmektedir. Alıcı dil ve ifade edici dil standart puanlarından sözel dil performansı hesaplanarak çocuğun dil gelişimi ile ilgili fikir sahibi olunmaktadır. Ölçeğin eğitimi ve uygulama izni araştırmacı tarafından alınmıştır.

Aile demografik bilgi formu. Ebeveynlere ait annenin ve babanın yaşı, öğrenim durumu, gelir durumu, çocuğun kardeş sayısı, çocuğa kitap okunma sıklığı ve evdeki çocuk kitabı sayısı ile ilgili bilgiler bu form aracılığıyla edinilmiştir.

Öğretmen demografik bilgi formu. Öğretmenlere ait cinsiyet, yaş, öğrenim durumu, kıdem yılı, en son mezun olunan okul, mezun olunan program ve görev yapılan okul türü demografik bilgi formu aracılığıyla elde edilmiştir.

\section{İşlem / Verilerin Toplanması}

Verilerin toplanması aşamasında, öğretmenlerden sınıflarındaki bir resimli öykü kitabını kullanarak sınıftaki tüm çocuklukların yer aldığı bir kitap okuma etkinliği gerçekleştirmeleri istenmiş ve bu etkinlikler video kaydına alınmıştır. Öğretmenin kitap okuma etkinliği sırasında okuduğu kitap ile eğitim ortamındaki kitap merkezinden rast gele seçilen 10 tane kitap araştırma kapsamında incelenmiştir. Her sınıfa iki gün gidilmiş; ilk gün çocuklara TiFALDi, ikinci gün ise TEDiL uygulaması yapılmıştır. TiFALDi ölçeğinin alıcı ve ifade edici dil alt boyutlarının uygulaması bir çocuk için ortalama on beş-yirmi dakika; TEDiL ölçeğinin alıcı ve ifade edici dil alt boyutlarının uygulaması bir çocuk için ortalama olarak yirmi-yirmi beş dakika sürmüştür. Çalışmada yer alacak çocukların belirlenebilmesi için ailelerden veli demografik bilgi formu aracılığıyla bilgi alınmıştır. Ekonomik düzeyin Tüik tarafından belirlenen yoksulluk sınııının altında olması ve annenin ve babanın eğitim düzeyinin yüksek olmaması gibi ölçütler belirlenerek, bu ölçütlere uyan ve ebeveynlerinin araştırmaya katılması için izin verdiği çocuklar örnekleme dâhil edilmiştir.

\section{Verilerin Analizi}

Araştırmanın problem cümlesi ve alt problemlere ilişkin elde edilen verilerin analizi için SPSS IBM 25 paket programı kullanıımıştır. Öğretmenlerin video kaydına alınan kitap okuma etkinliklerinin transkripsiyonu yapılmış; Kitap Okuma Etkinliği Öğretmen Değerlendirme Formu ile değerlendirilmiştir. Kitap Okuma Etkinliği Öğretmen Değerlendirme Formu ve Resimli Öykü Kitapları Değerlendirme Ölçeği aracılığıyla elde edilen puanlar ile çocukların TiFALDi ve TEDiL ölçekleri ile belirlenen sözcük bilgileri ve dil gelişimi puanları arasındaki ilişkinin test edilmesi için korelasyon analizi yapılmıştır. Kitap okuma etkinliklerinin niteliğinin alııı dil sözcük bilgisi ve alııı dil gelişimi ile ilişkisinin incelendiği korelasyon analizlerinde, KOD'un öyküyü etkili okuma, alıcı dili destekleme ve etkinlik ortamı alt boyutlarının puanları kullanılmıştır. Ifade edici sözcük bilgisi ve ifade edici dil gelişimi için yapılan korelasyon analizlerinde ise KOD'un öyküyü etkili okuma, ifade edici dili destekleme ve etkinlik ortamı alt boyutları kullanılmıştır. TEDiL ölçeği alıcı ve ifade edici dil puanlarından elde edilen sözel dil performansını anlamlı düzeyde yordayan değişkenlerin belirlenmesi için de basit doğrusal regresyon analizi yapılmıştır.

\section{Geçerlik ve Güvenirlik}

TiFALDi alıcı dil alt testi test-tekrar test güvenirliği .97 olarak bulunmuştur $(p<.01) .104$ maddenin iç tutarlılık katsayısı Cronbach Alpha $=.99$ olarak bulunmuştur. Yarıya bölme analizleri ile elde edilen tüm örneklem için Spearman-Brown değeri .99 olarak bulunmuştur. TiFALDi ifade edici dil kelime alt testinde ise test-tekrar test güvenirliği .97 olarak bulunmuştur $(p<.01) .80$ maddenin iç tutarlılık katsayısı Cronbach Alpha= .98 olarak bulunmuştur. Yarıya bölme analizleri ile elde edilen tüm örneklem için Spearman-Brown değeri 99 olarak elde edilmiştir.

TEDiL'in güvenirlik çalışmasında, alfa iç turtalılık katsayıları, farklı yaş grupları ve farkı demografik alt gruplarda her iki form ve alt testler için .86 ile .98 arasında bulunmuştur. Test-tekrar test yöntemi sonucunda korelasyon katsayıları A formu için Alıcı Dil .96 ve ífade Edici Dil .89 olarak 
bulunmuştur. Uygulayıcılar arası her iki formu ve alt testleri puanlamada \%100 bir uyuşma ve .99 korelasyon katsayısı bulunmuştur. TEDiL'in yapı geçerliği için yapılan analizlerde, Alıcı Dil ve ifade Edici Dil alt testleri için korelasyon katsayısının .87 ile .91 arasında olduğu görülmüştür.

Kitap Okuma Etkinliği Öğretmen Değerlendirme Formu’nun (KOD) kapsam ve yapı geçerliliği için iki ölçme ve değerlendirme uzmanı, dört alan uzmanı, bir dil uzmanı olmak üzere toplam yedi alan uzmanının görüşüne başvurulmuştur. Araştırmada yer alan öğretmenlerin dışındaki iki öğretmenin video kaydına alınan kitap okuma etkinliği ile pilot çalışma yapılmış ve ölçme aracındaki maddelere son hali verilmiştir. KOD ölçme aracı için puanlayıcılar arasındaki uyumu belirlemek için Spearman Korelasyon Katsayıları hesaplanmıştır. Birinci ve ikinci puanlayıcı arasındaki korelasyon katsayılarııın öyküyü etkili okuma boyutunda .988 , alıcı dili destekleme boyutunda .958 , ifade edici dili destekleme boyutunda .991 ve etkinlik ortamı boyutunda .982 olduğu görülmektedir. İki puanlayıcı arasında dört alt boyutta da 0.01 anlamlılık düzeyinde olumlu ve yüksek korelasyon bulunmuştur.

Resimli Öykü Kitaplarını Değerlendirme Ölçeği geçerlik ve güvenirlik çalışmaları sonucunda, Cronbach alfa katsayısı .94 olarak elde edilmiştir. Elde edilen bu sonuç .90'dan büyük olduğu için ölçek, güvenirliği yüksek bir ölçme aracı olarak kabul edebilir (George ve Mallery, 2003; Özdamar, 2002). Geçerlik ve güvenirlik çalışmaları kapsamında seçilen 200 kitaptan 30'u farklı bir okul öncesi eğitimi alanı uzmanı tarafından değerlendirilmiş ve puanlayıcı güvenirliği hesaplanmıştır. İki puanlayıcı arasındaki korelasyon katsayısı .92 olarak bulunmuştur. Yapılan analizler sonucunda Resimli Öykü Kitaplarını Değerlendirme Ölçeği'nin resimli öykü kitapların niteliğini belirlemek açısından geçerli ve güvenilir bir araç olduğunu destekleyen verilere ulaşılmıştır.

\section{Araştırma ve Yayın Etiği}

Bu çalışmada "Yükseköğretim Kurumları Bilimsel Araştırma ve Yayın Etiği Yönergesi" kapsamında uyulması belirtilen tüm kurallara uyulmuştur. Yönergenin ikinci bölümü olan "Bilimsel Araştırma ve Yayın Etiğine Aykırı Eylemler" başlığı altında belirtilen eylemlerden hiçbiri gerçekleştirilmemiştir.

\section{Etik Kurul izni}

Kurul adı $=$ Hacettepe Üniversitesi Etik Komisyonu

Karar tarihi $=26.04 .2016$

Belge sayı numarası $=431-1386$

\section{Bulgular \\ Araştırma sorularının sırasına göre araştırma bulguları ve bu bulgulara ilişkin değerlendirmelere yer verilmiştir.}

\section{Kitap Okuma Etkinliklerinin ve Resimli Öykü Kitaplarının Niteliği ile 5 Yaş Çocuklarının Alıcı Dil Sözcük Bilgisi ve Alıcı Dil Gelişimi Arasındaki iliş̧kinin Belirlenmesi}

5 yaş çocukların TiFALDi alıcı dil kelime alt testi ile elde edilen alıcı dil sözcük bilgisi puanlarının; Kitap Okuma Etkinliği Öğretmen Değerlendirme Formunun (KOD), Öyküyü Etkili Okuma, Alıcı Dili Destekleme ve Etkinlik Ortamı alt boyutlarından elde edilen puanlar ve Resimli Öykü Kitapları Değerlendirme Ölçeği'nden elde edilen puanlar ile ilişkisi incelenmiş ve Tablo 1'de gösterilmiştir. Kitap okuma etkinliklerinin ve resimli öykü kitaplarının niteliği ile 5 yaş çocuklarının alıcı dil sözcük bilgisi arasında anlamlı bir ilişki olup olmadığına ilişkin Spearman Brown korelasyon katsayıları hesaplanmıştır. 
Tablo 1.

KOD Alt Boyutlarının ve Resimli Öykü Kitaplarını Değerlendirme Ölçeği'nin Alıcı Dil Sözcük Bilgisi ile ilişkisine Yönelik Korelasyon Değerleri

\begin{tabular}{llllll}
\hline & \multicolumn{3}{c}{ Kitap Okuma Etkinliği Öğretmen Değerlendirme } & \\
& & $\begin{array}{l}\text { Öyküyü etkili } \\
\text { okuma puanı }\end{array}$ & $\begin{array}{l}\text { Alıcı dili } \\
\text { destekleme puanı }\end{array}$ & $\begin{array}{l}\text { Etkinlik } \\
\text { ortamı puanı }\end{array}$ & $\begin{array}{l}\text { Resimli öykü kitabı } \\
\text { değerlendirme } \\
\text { puanları }\end{array}$ \\
\hline TiFALDi alıcı dil & $\mathrm{r}$ & .183 & $.632^{* *}$ & $.597^{* *}$ & $.528^{*}$ \\
kelime alt testi & $\mathrm{p}$ & .427 & .002 & .004 & .014 \\
\hline
\end{tabular}

${ }^{*} p<0.05{ }^{* *} p<0.01$

Tablo 1 incelendiğinde, 5 yaş çocuklarının alıcı dil sözcük bilgisi puanları ile öğretmenin öyküyü etkili okuma puanları arasında 0.183 olan pozitif yönlü çok düşük düzeyde bir ilişki bulunmuş olup bulunan bu ilişki istatistiksel olarak anlamlı değildir ( $p>0.05$ ). 5 yaş çocuklarının alıcı dil sözcük bilgisi puanları ile öğretmenin alııı dili destekleme puanları arasında 0.632 olan pozitif yönlü orta düzeyde anlamlı bir ilişki bulunmuştur $(p<0.01)$. Öğretmenlerin alıcı dili destekleme puanları arttıkça, 5 yaş çocuklarının alıcı dil sözcük bilgilerinin arttığı görülmektedir. 5 yaş çocuklarının alıcı dil sözcük bilgisi puanları ile etkinlik ortamı puanları arasında 0.597 olan pozitif yönlü orta düzeyde anlamlı bir ilişki bulunmuştur $(p<0.01)$. Etkinlik ortamı ile ilgili puanlar arttıkça 5 yaş çocuklarının alıcı dil sözcük bilgilerinin de arttığı görülmektedir. 5 yaş çocuklarının alıcı dil sözcük bilgileri ile eğitim ortamındaki resimli öykü kitaplarının niteliği arasında 0.528 olan pozitif yönlü orta düzeyde anlamlı bir ilişki bulunmuştur $(p<0.05)$. Eğitim ortamındaki resimli öykü kitaplarının niteliği arttıkça 5 yaş çocuklarının alıcı dil sözcük bilgilerinin de arttığı saptanmıştır.

Tablo 2.

KOD Alt Boyutlarının ve Resimli Öykü Kitaplarını Değerlendirme Ölçeği'nin Alıcı Dil Gelişimi ile ilişkisine Yönelik Korelasyon Değerleri

\begin{tabular}{|c|c|c|c|c|c|}
\hline & & \multicolumn{3}{|c|}{$\begin{array}{c}\text { Kitap Okuma Etkinliği Öğretmen Değerlendirme } \\
\text { Formu (KOD) }\end{array}$} & \multirow[b]{2}{*}{$\begin{array}{l}\text { Resimli öykü kitabı } \\
\text { değerlendirme } \\
\text { puanları }\end{array}$} \\
\hline & & $\begin{array}{l}\text { Öyküyü etkili } \\
\text { okuma puanı }\end{array}$ & $\begin{array}{l}\text { Alıcı dili } \\
\text { destekleme puanı }\end{array}$ & $\begin{array}{l}\text { Etkinlik } \\
\text { ortamı puanı }\end{array}$ & \\
\hline TEDIL & $r$ & .362 & $.777^{* *}$ & $.591 * *$ & $.622 * *$ \\
\hline alıcı dil alt testi & $\mathrm{p}$ & .107 & .000 & .005 & .003 \\
\hline
\end{tabular}

$* * p<0.01$

5 yaş çocukların TEDiL alıcı dil alt testi ile elde edilen alıcı dil gelişimi puanlarının Kitap Okuma Etkinliği Öğretmen Değerlendirme Formunun (KOD), Öyküyü Etkili Okuma, Alıcı Dili Destekleme ve Etkinlik Ortamı alt boyutları puanları ve Resimli Öykü Kitapları Değerlendirme Ölçeğinden elde edilen puanlar ile olan ilişkisi incelenmiş ve Tablo 2 'de gösterilmiştir. Kitap okuma etkinliklerinin ve resimli öykü kitaplarının niteliği ile 5 yaş çocuklarının alıcı dil gelişimi arasında anlamlı bir ilişki olup olmadığına ilişkin Spearman Brown korelasyon katsayıları hesaplanmıştır.

5 yaş çocukların TEDiL'den aldıkları alıcı dil gelişimi puanları ile öğretmenin öyküyü etkili okuma puanları arasında 0.362 olan pozitif yönlü orta düzeyde bir ilişki bulunmuş olup bulunan bu ilişki anlamlı değildir ( $p>0.05$ ). Öğretmenin alıcı dili destekleme puanları arasında 0.777 olan pozitif yönlü yüksek düzeyde anlamlı bir ilişki bulunmuştur $(p<0.01)$. Öğretmenlerin alıcı dili destekleme puanları arttıkça 5 yaş çocuklarının alıcı dil gelişimi puanları da artmaktadır. 5 yaş çocuklarının alıcı dil gelişimi puanları ile etkinlik ortamı puanları arasında ise 0.591 olan pozitif yönlü orta düzeyde anlamlı bir ilişki bulunmuştur $(p<0.01)$. Öğretmenin etkinlik ortamına ait davranışlarının niteliği arttıkça 5 yaş çocuklarının alıcı dil gelişimleri artmaktadır. Eğitim ortamındaki resimli öykü kitaplarının niteliği arasında 0.622 olan pozitif 
Kitap Okuma Etkinliklerinin ve Resimli Öykü Kitaplarının Niteliği ile Sosyoekonomik Açıdan Dezavantajlı Çocukların Dil Gelişimleri Arasındaki ilişki

yönlü orta düzeyde anlamlı bir ilişki bulunmuştur ( $p<0.05)$. Eğitim ortamındaki resimli öykü kitaplarının niteliği arttıkça 5 yaş çocuklarının alıcı dil gelişimlerinin de arttığı saptanmıştır.

Kitap Okuma Etkinliklerinin ve Resimli Öykü Kitaplarının Niteliği ile 5 Yaş Çocuklarının ífade Edici Sözcük Bilgisi ve ifade Edici Dil Gelişimi Arasındaki iliş̧inin Belirlenmesi

5 yaş çocukların TiFALDi ifade edici dil kelime alt testi puanları ile elde edilen ifade edici dil sözcük bilgisi puanlarının, Kitap Okuma Etkinliği Öğretmen Değerlendirme Formunun (KOD), Etkili Okuma, Ifade Edici Dili Destekleme ve Etkinlik Ortamı alt boyutları puanları ve Resimli Öykü Kitapları Değerlendirme Ölçeği puanları ile olan ilişkisi incelenmiş ve Tablo 3'te gösterilmiştir. Kitap okuma etkinliklerinin ve resimli öykü kitaplarının niteliği ile 5 yaş çocuklarının ifade edici dil sözcük bilgisi ve ifade edici dil gelişimi arasında anlamlı bir ilişki olup olmadığına ilişkin Spearman Brown korelasyon katsayıları hesaplanmıştır.

Tablo 3.

KOD Alt Boyutlarının ve Resimli Öykü Kitaplarını Değerlendirme Ölçeği'nin Ifade Edici Dil Sözcük Bilgisi ile ilişskisine Yönelik Korelasyon Değerleri

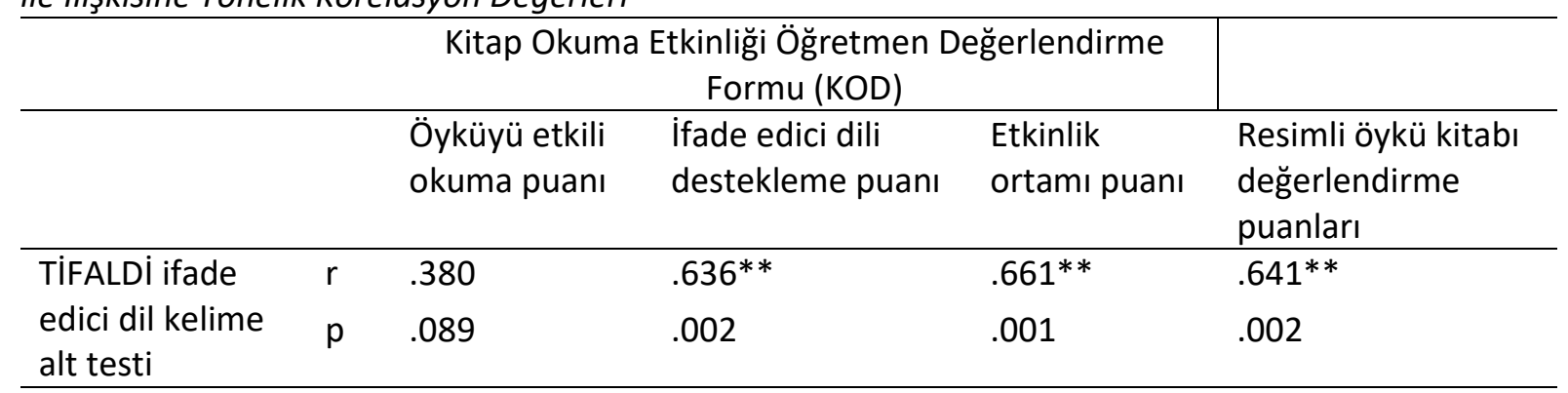

Tablo 3 incelendiğinde, 5 yaş çocuklarının ifade edici dil sözcük bilgisi puanları ile öğretmenin öyküyü etkili okuma puanları arasında 0.380 olan pozitif yönlü düşük düzeyde bir ilişki bulunmuş olup bulunan bu ilişki anlamlı değildir ( $p>0.05$ ). Çocukların ifade edici sözcük bilgisi puanları ile öğretmenin ifade edici dili destekleme puanları arasında 0.636 olan pozitif yönlü orta düzeyde anlamlı bir ilişki bulunmuştur $(p<0.01)$. Öğretmenlerin ifade edici dili destekleme puanları arttıkça 5 yaş çocuklarının ifade edici dil sözcük bilgileri de artmaktadır. 5 yaş çocuklarının ifade edici dil sözcük bilgisi puanları ile etkinlik ortamı puanları arasında 0.661 olan pozitif yönlü orta düzeyde anlamlı bir ilişki bulunmuştur $(\mathrm{p}<0.01)$. Bir başka deyişle etkinlik ortamı puanları arttıkça 5 yaş çocuklarının ifade edici dil sözcük bilgileri de artmaktadır. 5 yaş çocuklarının ifade edici dil sözcük bilgisi puanları ile okunan resimli öykü kitabının değerlendirme puanları arasında 0.641 olan pozitif yönlü orta düzeyde anlamlı bir ilişki bulunmuştur $(p<0.01)$. Resimli öykü kitabının değerlendirme puanları arttıkça 5 yaş çocuklarının ifade edici dil sözcük bilgilerinin arttığı görülmektedir.

Tablo 4.

KOD Alt Boyutlarının ve Resimli Öykü Kitaplarını Değerlendirme Ölçeği'nin Ifade Edici Dil Gelişsimi ile ilişkisine Yönelik Korelasyon Değerleri

\begin{tabular}{llllll}
\hline & \multicolumn{3}{c}{ Kitap Okuma Etkinliği Öğretmen Değerlendirme } & \\
& & $\begin{array}{l}\text { Formu (KOD) } \\
\text { Oküüü etkili }\end{array}$ & $\begin{array}{l}\text { ifade edici dili } \\
\text { okuma puanı }\end{array}$ & $\begin{array}{l}\text { Etkinlik } \\
\text { ortamı puanı }\end{array}$ & $\begin{array}{l}\text { Resimli öykü kitabı puanı } \\
\text { değerlendirme } \\
\text { puanları }\end{array}$ \\
\hline TEDiL ifade edici & $\mathrm{r}$ & .323 & $.732^{* *}$ & $.628^{* *}$ & $.687^{* *}$ \\
dil alt testi & $\mathrm{p}$ & .153 & .000 & .002 & .001 \\
\hline
\end{tabular}

\footnotetext{
$* * p<0.01$
} 
5 yaş çocuklarının TEDiL ifade edici dil alt testinden elde edilen ifade edici dil gelişimi puanlarının, Kitap Okuma Etkinliği Öğretmen Değerlendirme Formunun (KOD), Öyküyü Etkili Okuma, Ifade Edici Dili Destekleme ve Etkinlik Ortamı alt boyutları puanları ve Resimli Öykü Kitapları Değerlendirme Ölçeğinden elde edilen puanlar ile olan ilişkisi Tablo 4'te gösterilmiştir. Kitap okuma etkinliklerinin ve resimli öykü kitaplarının niteliği ile 5 yaş çocuklarının ifade edici dil gelişimi arasında anlamlı bir ilişki olup olmadığına ilişkin Spearman Brown korelasyon katsayıları hesaplanmıştır.

Tablo 4 incelendiğinde, 5 yaş çocuklarının ifade edici dil gelişimi düzeyleri ile öğretmenin öyküyü etkili okuma puanları arasında 0.323 olan pozitif yönlü düşük düzeyde bir ilişki bulunmuş olup bulunan bu ilişki anlamlı değildir ( $p>0.05$ ). 5 yaş çocuklarının ifade edici dil gelişimleri ile öğretmenin ifade edici dili destekleme puanları arasında 0.732 olan pozitif yönlü yüksek düzeyde anlamlı bir ilişki bulunmuştur $(p<0.01)$. Öğretmenin ifade edici dili destekleme puanları arttıkça 5 yaş çocuklarının ifade edici dil gelişim düzeyleri artmaktadır. 5 yaş çocuklarının ifade edici dil gelişimleri ile eğitim ortamı puanları arasında 0.628 olan pozitif yönlü orta düzeyde anlamlı bir ilişki bulunmuştur $(p<0.01)$. Etkinlik ortamı puanları arttıkça, 5 yaş çocuklarının ifade edici dil gelişim düzeyleri de artmaktadır. 5 yaş çocuklarının ifade edici dil gelişimleri ile resimli öykü kitapları değerlendirme ölçeği puanları arasında 0.687 olan pozitif yönlü orta düzeyde anlamlı bir ilişki bulunmuştur $(p<0.01)$. Bir başka deyişle resimli öykü kitaplarının niteliği arttıkça 5 yaş çocuklarının ifade edici dil gelişim düzeyleri de artmaktadır.

\section{Kitap Okuma Etkinliklerinin ve Resimli Öykü Kitaplarının Niteliği ile 5 Yaş Çocuklarının Sözel Dil Performansı Arasındaki İlişkinin Belirlenmesi}

5 yaş çocukların TEDiL ile elde edilen sözel dil performansı puanlarının, Kitap Okuma Etkinliği Öğretmen Değerlendirme Formunun (KOD), Öyküyü Etkili Okuma, Alıcı Dili Destekleme, İfade Edici Dili Destekleme ve Etkinlik Ortamı alt boyutları puanları ve Resimli Öykü Kitapları Değerlendirme Ölçeğinden elde edilen puanlar ile olan ilişkisi incelenmiş ve Tablo 5 'te gösterilmiştir. Kitap okuma etkinliklerinin ve resimli öykü kitaplarının niteliği ile 5 yaş çocuklarının sözel dil gelişimleri arasında anlamlı bir ilişki olup olmadığına ilişkin Spearman Brown korelasyon katsayıları hesaplanmıştır.

Tablo 5.

KOD Alt Boyutlarının ve Resimli Öykü Kitaplarını Değerlendirme Ölçeği'nin Sözel Dil Performansı Ille ilişkisine Yönelik Korelasyon Değerleri

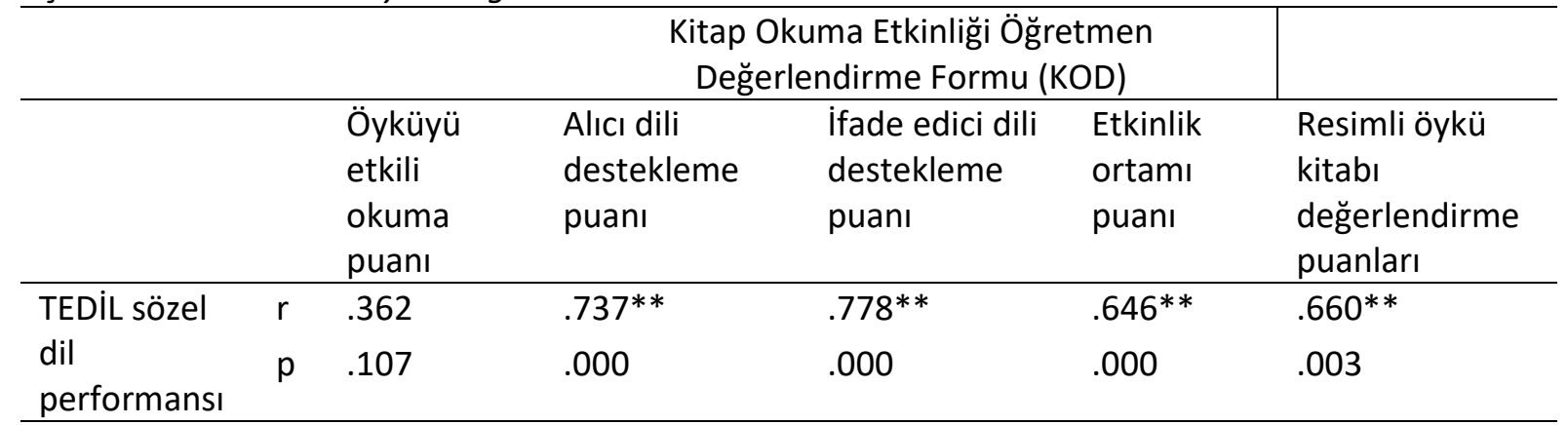

$* * p<0.01$

Tablo 5'e göre 5 yaş çocuklarının sözel dil performansları ile öğretmenin öyküyü etkili okuma puanları arasında 0.362 olan pozitif yönlü düşük düzeyde bir ilişki bulunmuş olup bulunan bu ilişki anlamlı değildir ( $p>0.05$ ). 5 yaş çocuklarının sözel dil performansları ile öğretmenlerin alıcı dili destekleme puanları arasında 0.737 olan pozitif yönlü yüksek düzeyde anlamlı bir ilişki bulunmuştur $(p<0.01)$. Öğretmenlerin alıcı dili destekleme puanları arttıkça 5 yaş çocuklarının sözel dil performansları da artmaktadır. 5 yaş çocuklarının sözel dil performansları ile öğretmenin ifade edici dili destekleme puanları arasında 0.778 olan pozitif yönlü yüksek düzeyde anlamlı bir ilişki bulunmuştur $(p<0.01)$. Öğretmenin ifade edici dili destekleme puanları arttıkça 5 yaş çocuklarının sözel dil performansları da artmaktadır. 5 yaş çocuklarının sözel dil performansları ile etkinlik ortamı puanları arasında 0.646 olan pozitif yönlü orta düzeyde anlamlı bir ilişki bulunmuştur $(p<0.01)$. Etkinlik ortamı 
Kitap Okuma Etkinliklerinin ve Resimli Öykü Kitaplarının Niteliği ile Sosyoekonomik Açıdan Dezavantajlı Çocukların Dil Gelişimleri Arasındaki ilişki

puanları arttıkça 5 yaş çocuklarının sözel dil performansları artmaktadır. 5 yaş çocuklarının TEDiL ölçeği sözel dil performansları ile resimli öykü kitaplarını değerlendirme puanları arasında 0.660 olan pozitif yönlü orta düzeyde anlamlı bir ilişki bulunmuştur $(p<0.01)$. Bir başka deyişle resimli öykü kitaplarını değerlendirme puanları arttıkça 5 yaş çocuklarının sözel dil performansları artmaktadır.

\section{Yaş Çocuklarının Sözel Dil Performansını Anlamlı Olarak Açıklayan Değişkenlerin Belirlenmesi}

5 yaş çocuklarının sözel dil performansını anlamlı olarak açıklayan değişkenlere yönelik yapılan regresyon analizine ilişkin değerler Tablo 6'da gösterilmiştir.

Tablo 6.

Sözel Dil Performansını Anlamlı Olarak Açıklayan Değişkenler

\begin{tabular}{llllll}
\hline Değişkenler & $\mathrm{B}$ & Sd. Hata & $\beta$ & $\mathrm{t}$ & $\mathrm{p}$ \\
\hline Sabit & -.494 & 16.921 & & -.029 & .977 \\
Annenin yaşı & -.127 & .279 & -.048 & -.456 & .649 \\
Babanın yaşı & .180 & .240 & .078 & .747 & .456 \\
Anne eğitim düzeyi & 1.298 & 1.354 & .074 & .959 & .339 \\
Baba eğitim düzeyi & -.615 & 1.296 & -.035 & -.474 & .636 \\
Ailenin aylık geliri & 4.052 & 1.651 & .162 & 2.454 & $.015^{*}$ \\
Kardeş sayısı & -.776 & .978 & -.048 & -.793 & .429 \\
Ailenin çocuğa kitap okuma sıklığı & 3.390 & 1.539 & .154 & 2.202 & $.029 *$ \\
Evdeki kitap sayısı & -.257 & 1.558 & -.012 & -.165 & .869 \\
Tifaldi alıcı dil & .447 & .093 & .358 & 4.786 & $.000^{*}$ \\
Tifaldi ifade edici dil & .246 & .086 & .202 & 2.860 & $.005^{*}$ \\
Etkili okuma puanları & -.106 & .511 & -.017 & -.208 & .835 \\
Alııı dili destekleme puanları & -.045 & .491 & -.011 & -.091 & .927 \\
Ifade edici dili destekleme puanları & 1.333 & .435 & .310 & 3.061 & $.003^{*}$ \\
Etkinlik ortamı puanları & -.485 & .953 & -.067 & -.509 & .611 \\
Resimli öykü kitapları puanları & -.400 & .336 & -.134 & -1.190 & .236 \\
Öğretmenin yaşı & .082 & .477 & .041 & .171 & .864 \\
Öğretmenin kıdemi & -.141 & .468 & -.074 & -.301 & .764 \\
Öğretmenin eğitim düzeyi & 3.226 & 2.019 & .119 & 1.598 & .112 \\
Okul türü & .354 & 2.059 & .011 & .172 & .864 \\
\hline
\end{tabular}

$\mathrm{F}=11.094 p<0.05$

$\mathrm{R}=.753, \mathrm{R} 2=.567$

Tablo 6 incelendiğinde, yapılan basit doğrusal regresyon analizi sonucunda, 5 yaş çocuklarının sözel dil performansını anlamlı olarak yordayan değişkenlerin sırasıyla ailenin aylık geliri, ailenin çocuğa kitap okuma sıklığı, çocuğun alıcı dil sözcük bilgisi, çocuğun ifade edici dil sözcük bilgisi ile öğretmenin ifade edici dili destekleme puanları olduğu görülmektedir. Bu değişkenler, 5 yaş çocuklarının TEDí ölçeğinin alıcı ve ifade edici dil gelişimleri puanları ile elde edilen sözel dil performansına ait toplam varyansın \%56'sını açıklamaktadır ( $p<0.05, \mathrm{R} 2=.567)$.

\section{Tartışma ve Sonuç}

Bu çalışmada, okul öncesi öğretmenlerinin kitap okuma etkinlikleri sırasında alıcı dili destekleme davranışlarının ve etkinlik ortamının niteliği ile alt sosyoekonomik düzeydeki 5 yaş grubundaki çocukların alıcı dil sözcük bilgileri ve alıcı dil gelişimleri arasında anlamlı ve pozitif bir ilişki olduğu belirlenmiştir. Öğretmenlerin öyküyü etkili okumaları ile çocukların alıcı dil sözcük bilgisi ve dil gelişimi puanları arasında ise anlamlı bir ilişki bulunamamıştır. Resimli öykü kitaplarının niteliği ile alıcı dil sözcük bilgisi ve alıcı dil gelişimi arasında anlamlı ve pozitif bir ilişki olduğu bulunmuştur.

Bu çalışmanın bulguları ile benzer olarak, yapılan araştırmalarda, öğretmenlerin kitap okuma etkinliklerinde alıcı dili destekleme davranışları arasında sayılan öykü ile bağlantılı konuşmalarının, zengin bir dil kullanmalarııı ve dili kullanmada model olmalarının çocukların dil gelişimi ile ilişkili 
olduğu ortaya koyulmuştur (Beals ve diğ., 1994; Bowers ve Vasilyeva, 2011; Gest ve diğ., 2006; Hindman ve diğ., 2012; Mascareño ve diğ., 2016). Tahminde bulunma, öykünün öğelerini analiz etme, kelimelerin anlamlarını tartışma gibi çocuk merkezli konuşmaların artması, çocukların sözcük bilgilerinin artması ile sonuçlanmaktadır (Dickinson ve Smith, 1991; Wasik 2010). Yapılan çalışmalar kitap okuma etkinliklerinde hedef sözcükler seçilerek anlamlarının açıklanmasının özellikle alıcı dil sözcük bilgisi az olan çocuklar üzerinde olumlu bir etkiye sahip olduğunu göstermektedir (Coyne, Simmons, Kame'enui ve Stoolmiller, 2004; Kindle, 2011; Lipsky, 2011; Silverman, Crandell ve Carlis; 2013). Tepetaş Cengiz (2015) tarafından yapılan çalışmada da öğretmenlerin kitap okuma etkinliklerinde dili kullanma, soyut düşünme, detaylandırma becerilerini desteklemeleri ile çocukların alıcı dil gelişimleri arasında anlamlı ve pozitif ilişki bulunmuştur. Bu çalışmada da öğretmenlerin öykü kitabını tanıtma, öyküyü ayrıntılandırma ve dili kullanmada model olma davranışları kapsamında belirlenen alıcı dili destekleyen uygulamalarının niteliği ile çocukların alıcı dil sözcük bilgisi ve alıcı dil gelişimi arasında anlamlı bir ilişki olduğu sonucuna varılmıştır.

Etkinlik ortamının niteliği kapsamında, kitap okuma etkinliklerinde olumlu öğretmen davranışları ile çocukların alıcı dil sözcük bilgisi ve alıcı dil gelişimi ilişkili bulunmuştur. Araştırmadan elde edilen sonuç ilgili alan yazın tarafından desteklenmektedir. Sınıf içinde gerçekleşen dil açısından duyarlı konuşmaların çocukların bilişsel, dil ve sosyal duygusal gelişim alanlarındaki becerileri ile güçlü bir şekilde ilişkili olduğu ortaya çıkmıştır (Mashburn, ve diğ., 2008). Tepetaş Cengiz (2015) tarafından yapılan çalışmada, kitap okuma etkinliğinin olumlu bir sınıf ikliminde gerçekleşmesi ile çocukların alıcı dil gelişimi arasında anlamlı bir ilişki bulunmuştur. Sınıfta gerçekleşen tartışmalar, çocukların kendi bilgilerini yapılandırılmalarını sağlayarak, yeni düşünüş tarzı geliştirmelerini sağlamaktadır (Bruning, Schraw ve Norby, 2014). Bu ilgiyi yaratmada ve çocukların bilgiyi yapılandırmalarında öğretmenler önemli bir rol oynamaktadır. Gianvecchio ve French (2002), alıcı dil kelime bilgisi düşük olan çocukların, öykünün başlangıcına dikkatlerini vermekte zorlanmakta olduklarını ve öğretmenlerin öyküden bağımsız bir durum için kesinti yaptığında da bu çocukların ilgilerinin daha kolay kaybolduğunu belirtmektedirler. Alıcı dil sözcük bilgisi, çocukların öykü etkinliklerine dikkatlerini sürdürmeleri üzerinde etkili olmaktadır. Öğretmenlerin kitap okuma etkinliği boyunca yaptığı olumlu ve olumsuz yorumlar çocukların dikkatlerini etkilemektedir. Bu nedenle öğretmenlerin çocuklara olumlu geri bildirim vermeleri konusunda hassas olmaları etkinlik ortamının niteliği açısından önem taşıdığı şeklinde yorumlanabilir.

Öykünün etkili bir şekilde okunması, çocukların dikkatini çekmek açısından önemli bir etken olmasına rağmen (De Temple ve Snow, 2003), bu çalışmada bu alt boyut ile çocukların alıcı dil sözcük bilgisi ve alıcı dil gelişimi arasında anlamlı bir ilişki bulunamamıştır. Ses tonunda yapılan değişiklikler sözcüklerin anlamını belirlemekte ve farklı tonlamalar anlamı değiştirdiği için dil gelişimi açısından önemli olmaktadır (McBride, 2016). Bu nedenle maddeler öğretmenlerin kitap okuma etkinliklerinde ses tonunu ayarlamaya, vurgulamalara, jest ve mimikleri kullanmaya dikkat etmeleri kapsamında belirlenmiştir. Bu alt boyutun çocukların dil gelişimi ile ilişkili çıkmaması ölçme aracının özelliklerinden kaynaklandığı şeklinde yorumlanabilir. Justice, Zucker ve Sofka (2010) da etkili okuma maddeleri olarak ele alınan ses tonu, jest ve mimik kapsamındaki değerlendirmelerin standart bir şekilde yapılmasının ve bu davranışların hangi düzeylerde gerçekleştiğinin belirlenmesinin zorluğuna işaret etmektedirler. Bu boyutun farklı çalışmalarda tekrar ele alınması önerilmektedir.

Bu çalışmada resimli öykü kitaplarının niteliği, çocukların alıcı dil sözcük bilgisi ve alıcı dil gelişimi ile ilişkili bulunmuştur. Bu sonuç alan yazın tarafından desteklenmektedir. Montag, Jones ve Smith (2015), çocuklara nitelikli kitaplar okumanın özellikle dil gelişimi açısından yararlı olduğunu belirtmektedir. Yapılan araştırmalar, nitelikli resimli öykü kitaplarında kullanılan dil yapılarının ve sözcüklerin, günlük konuşma diline göre daha gelişmiş ve öğretici olduğunu göstermektedir (Crain Thoreson, Dahlin ve Powell, 2001; Hayes ve Ahrens, 1988). Price, Van Kleeck ve Huberty (2009), öykü kitaplarının metinlerindeki sözce uzunluğunun yetişkin ifadelerinin sözce uzunluğundan neredeyse iki kat fazla olduğuna ve cümle yapıları açısından da yetişkin konuşmalarına göre daha zengin olduğuna dikkat çekmektedir. Resimli öykü kitaplarının metninin, küçük çocuklar için önemli bir sözcük ve dil kaynağı olma özelliğini taşıdığı görülmektedir. Verhallen ve Bus (2011), öykü kitabında yer alan resimlemelerin çocukların öykünün anlamını kavramalarının üzerinde etkili olduğunu ortaya 
çıkarmışlardır. Resimlemelerin öyküyü yansıtma niteliği bu açıdan önem taşımaktadır. Öykü kitabındaki resimlemeler çocukların dikkatini çekmekte ve öyküyü anlamlandırmalarında etkili olmaktadır. Bu çalışmadan elde edilen resimli öykü kitaplarının niteliğinin çocukların dil gelişimi ile ilişkili olduğu sonucu da resimli öykü kitaplarının dil gelişimi açısından önemini vurgulamaktadır.

Bu çalışmada alıcı dil sözcük bilgisi ve alıcı dil gelişimi ile birlikte ifade edici dil sözcük bilgisi ve ifade edici dil gelişimi de incelenmiştir. Okul öncesi öğretmenlerinin kitap okuma etkinliği sırasında ifade edici dili destekleme davranışlarının ve etkinlik ortamının niteliği ile alt sosyoekonomik düzeydeki 5 yaş grubundaki çocukların ifade edici dil sözcük bilgileri ve ifade edici dil gelişimleri arasında anlamlı ve pozitif bir ilişki olduğu belirlenmiştir. Öğretmenlerin öyküyü etkili okumaları ile çocukların ifade edici dil sözcük bilgisi ve dil gelişimi puanları arasında ise anlamlı bir ilişki bulunamamıştır. Resimli öykü kitaplarının niteliği ile ifade edici dil sözcük bilgisi ve ifade edici dil gelişimi arasında anlamlı ve pozitif bir ilişki olduğu bulunmuştur.

Bowers ve Vasilyeva (2011) tarafından yapılan çalışmada, okul öncesi eğitimde öğretmenlerin kullandığı sözcüklerin ve dilin zenginliği ile çocukların ifade edici sözcük bilgisi ilişkili bulunmuştur. Konuşulan dilin zenginliğinin yanı sıra kitap okuma etkinlikleri bilişsel açıdan düşündürücü sorular sormaları için öğretmenlere fırsat yaratmaktadır (Massey, Pence, Justice ve Bowles, 2008). Sénéchal (1997) yaptığı çalışmada, çocuklara yeni sözcükler üretmelerini gerektiren tanımlamaya yönelik sorular sorulmasının, ifade edici sözcük bilgisi için güçlü bir yordayıcı olduğu sonucuna ulaşmıştır. Öykü ile bağlantılı açık uçlu sorular sorulmasının okul öncesi eğitim alan risk altındaki çocukların sözcük bilgileri üzerinde olumlu etkileri olmaktadır (Bay ve Şimşek Çetin, 2015; Van Kleeck, Vander Woude ve Hammett, 2006). Sözcük kazanımında en çok artışın kitap okuma etkinliği boyunca çocuklara sorular sorulması ile gerçekleştiğini gösteren araştırmalar vardır (Walsh ve Blewitt, 2006; Gonzalez, Pollard Durodola, Simmons, Taylor, Davis, Fogarty ve Simmons, 2014; Van Kleeck, 2008). Zucker, Justice, Piasta ve Kaderavek (2010) yaptıkları çalışmada, kitap okuma etkinliklerinde okul öncesi öğretmenlerinin, çocukları daha kompleks konuşmalara katılmaya teşvik etmeleri için çıkarıma dayalı soruları kullanabileceklerini göstermişlerdir. Bu çalışmada da öğretmenlerin çocuklara neden sonuç ilişkisi kurabilecekleri, karşılaştırma yapabilecekleri sorular sormaları ile çocukların ifade edici sözcük bilgisi ve dil gelişimi ile anlamlı bir ilişki olduğu ortaya çıkmıştır.

Bu çalışmada, etkinlik ortamının niteliği, çocukların ifade edici dil sözcük bilgisi ve ifade edici dil gelişimi ile istatistiksel açıdan anlamlı ve pozitif ilişkili olarak bulunmuştur. Pianta, Nimetz ve Bennett (1997) tarafından yapılan çalışmada, okul öncesi eğitimde öğretmenin duyarlılığı ve hassasiyeti hem çocukların birbirleri arasındaki hem de çocuk ve öğretmen arasındaki etkileşimin pozitiflik düzeyi, çocukların ifade edici dil gelişimi ile ilişkili bulunmuştur. Çocuklar, kendilerini duygusal açıdan güvende hissettikleri ve sosyalleşebildikleri nitelikli bir eğitim ortamında, dili kullanarak sınıf içinde kendilerini rahat bir şekilde ifade edebilmekte; bu durum çocukların özellikle ifade edici dil gelişimleri açısından yararlı olmaktadır (Curby, Grimm ve Pianta, 2010; Girolametto ve Weitzman, 2002). Bu çalışmanın bulguları da bu durumu desteklemektedir. Connor ve diğ., (2006) tarafından yapılan çalışmada, küçük grupla ile gerçekleştirilen etkinliklerde etkileşimin daha yoğun olduğu bulunmuştur. Öğretmenlerin hem küçük hem de büyük grupla kitap okuma etkinlikleri gerçekleştirmeye önem vermeleri gerektiği yorumu yapılabilir.

Bu çalışmada etkili okuma boyutunda, öykü kitabını okurken uygun bir hızda ve ses tonu ile okuma, vurgu ve tonlamalara dikkat etme, jest ve mimik kullanma, karakterler için sesinde değişiklik yapma kapsamında ele alınan davranışlar, çocukların ifade edici dil sözcük bilgileri ve gelişimleri ile ilişkili bulunmamıştır. Oysa Moschovaki, Meadows ve Pellegrini (2007) tarafından yapılan araştırmada, öğretmenlerin kitapları etkili bir şekilde sunmaları ile çocukların tepkileri arasında anlamlı bir ilişki bulunmuştur. Özellikle öğretmenlerin kişisel yorumları çocukların etkili katılımını artıırmış, öğretmenlerin tekrarlamaları çocukların da tekrarlamalarını ve taklitlerini ortaya çıkarmış; öğretmenlerin ses tonlamalarına dikkat etmeleri çocukların kişisel olarak yorumda bulunmalarını sağlamıştır. Bu boyutun alıı dil gelişimi ile ilişkisinin tartışmasında belirtildiği gibi ifade edici dil gelişimi açısından da farklı araştırmalarda ele alınması önerilmektedir.

Bu çalışmada, resimli öykü kitaplarının niteliği ile çocukların ifade edici sözcük bilgisi ve dil gelişimi arasında ilişki olduğu sonucuna ulaşılmıştır. Van Kleeck, (2008), kitap okumanın dil becerileri 
üzerinde etkili olmasının birinci nedenini metnin sabit olması, ikinci nedenini öykü kitabı kapsamında yapılan tartışmaların çocukları doğal bir şekilde çıkarım yapmaya yöneltmesi, üçüncü nedeninin ise kitap okuma etkinliklerinin, çocukların sözel dil gelişimini desteklemesi olarak göstermektedir. Kitap okuma etkinliklerinde okunacak kitapların, çocuklar açısından ilgi çekici karakterler ve çizimler içeren; öğretmene akıcı ve etkileyici bir okuma yapmak için fırsat sunan kitaplar arasından seçilmesi önerilmektedir (Lane ve Wright, 2007). Çünkü kısa ve basit kitapların, daha ayrıntılı olay örgüsü içeren öykü kitapları kadar tartışmaya teşvik edici olmadığı belirtilmektedir (Dickinson ve Keebler, 1989).

Yapılan regresyon analizi sonucunda, 5 yaş çocuklarının sözel dil performansını anlamlı olarak açıklayan değişkenlerin sırasıyla ailenin aylık geliri, ailenin çocuğa kitap okuma sıklığı, çocuğun alıcı dil sözcük bilgisi, çocuğun ifade edici dil sözcük bilgisi ile öğretmenin ifade edici dili destekleme puanları olduğu sonucuna ulaşılmıştır. Bu çalışmada alt sosyoekonomik düzeyde yer alan ailelere yer verilse de alt sosyoekonomik düzeydeki ailelerin arasındaki gelir farklılıklarının da çocukların dil gelişimi ile ilişkili olduğu bulgusuna ulaşılmıştır. Sosyoekonomik düzeyin dil gelişimi açısından çevresel faktörleri belirlediği düşünülmektedir ve sosyoekonomik düzey pek çok araştırmada dil gelişimi ile ilişkili bir değişken olarak karşımıza çıkmaktadır (Berger, Paxson ve Waldfogel, 2009; Ergin, 2012; Farkas ve Beron, 2004; Hart ve Risley, 1995, 2003; Letts, Edwards, Sinka, Schaefer ve Gibbons, 2013; Locke, Ginsborg ve Peers, 2002; Peers, Lloyd ve Foster, 2000; Walker ve diğ., 1994; Yıldıım, 2008). Gelir düzeyi yüksek olan çocukların gelir düzeyi düşük olan çocuklara göre dil gelişim puanları daha yüksek bulunmuştur. Bunun sonucu olarak dil gelişimi ile gelir seviyesi arasında anlamlı bir ilişki olduğu sonucuna ulaşılmıştır. Roy ve Chiat (2013), düşük sosyoekonomik düzeydeki çocukların dil gelişim düzeylerinin düşük olabileceğini kabul etmekle birlikte çocukların zengin ortamlarda desteklenmeleri durumunda tam potansiyellerini gerçekleştirebileceklerini belirtmektedir.

Bu çalışmada ebeveynlerin kitap okuma sıkıklarının çocukların dil gelişimini anlamlı düzeyde açıkladığı sonucuna ulaşılmışır. Bu konu ile ilgili yapılan araştırmalarda da benzer sonuçlar elde edilmiştir. Yapılan çalışmalar ebeveynlerin çocuklarına kitap okuma sıklığı ile çocukların dil gelişimleri arasında anlamlı bir ilişki olduğunu göstermektedir (Aram ve Shapira, 2012; Bus, Van IJzendoorn ve Pellegrini, 1995; Debaryshe, 1993; Sénéchal ve diğ., 1998). Aile ile ilgili değişkenler olan aylık gelir ve kitap okuma sıklığının çocukların sözel dil performansını anlamlı şekilde açıklaması dil gelişiminde ev ortamının da oldukça önemli olduğunu ortaya koymaktadır.

Bu çalışmada sözel dil performansını anlamlı düzeyde açıklayan diğer değişkenlerin alıcı dil sözcük bilgisi ve ifade edici dil sözcük bilgisi olduğu sonucuna ulaşılımıştır. Sözel öğrenmenin ilk aşaması sözcük öğrenme olarak karşımıza çıkmaktadır (Arı, 2018). Sözcük öğrenimi, dilin edinilmesinde temel bir yapı taşı ve önemli bir dil bileşeni olarak tanımlanmaktadır (Pinker ve Jackendoff, 2005). Alıcı dil sözcük bilgisi bebeklikten itibaren sözel dil gelişiminin temellerini oluşturmaktadır (Christensen, Zubrick, Lawrance, Mitrou ve Taylor, 2014; Graf Estes, Edward ve Saffran, 2011). Dixon ve Marchmen (2007), 16-30 aylık çocuklarla yaptıkları çalışmada gramer ve sözcük bilgisinin birbirine paralel olarak geliştiğini ortaya koymuştur. Marchman ve Fernald (2008) tarafından yapılan çalışmada da 25 aylık çocukların sözcük bilgilerinin, 8 yaşına geldiklerinde dil gelişimlerini yordadığı bulunmuştur. Song ve diğ. (2015) tarafından yapılan, 4 yaşından 11 yaşına kadar çocukların dil gelişimi ve okuma becerileri açısından incelendiği boylamsal çalışmada da erken çocukluk dönemindeki sözcük bilgisinin çocukların sonraki dil gelişimi açısından oldukça önemli bir yordayıcı olduğu bulunmuştur. Lee (2012) tarafından 1.073 çocukla yapılan başka bir boylamsal çalışmada sözcük bilgisi ile dil gelişimi arasındaki ilişki ortaya konmuş; 2 yaşındaki çocukların sözcük bilgisinin 11 yaşına geldiklerinde dil gelişimini anlamlı olarak yordadığı sonucuna ulaşılmıştır. Yapılan farklı çalışmalar, bu çalışmanın sonuçlarına benzer olarak sözcük bilgisinin dil gelişiminin önemli bir yordayıcısı olduğunu ortaya koymaktadır.

Sözel dil performansını anlamlı düzeyde açıklayan diğer bir değişken ifade edici dili destekleme olarak bulunmuştur. İfade edici dili destekleme alt boyutu, çocukların ifade edici dil sözcük bilgisi ve dil gelişimi ile ilişkili bulunmuş ve bir önceki bölümdeki tartışmada ayrıntılı bir şekilde yer verilmiştir. Küçük yaştaki çocukların ifade edici dil gelişimlerinin genetik ve çevresel faktörler açısından incelendiği bir çalışmada çevresel faktörlerin dil gelişimindeki değişimin \%54 ile \%78'ini oluşturduğu ortaya koyulmuştur (Van Hulle, Goldsmith ve Lemery, 2004). Ifade edici dili desteklemenin, çocukların dil 
gelişiminin anlamlı bir yordayıcısı olarak bulunması öğretmenlerin ifade edici dili desteklemelerinin önemini bir kez daha ortaya koymaktadır.

Bu araştırma kapsamında 5 yaş grubundaki çocukların dil gelişimleri incelenmiştir. Bundan sonra yapılacak araştırmalarda daha küçük yaş grupları ile benzer bir araştırma gerçekleştirilebilir. Bu çalışmada öyküyü etkili okuma ile çocukların alıcı ve ifade edici sözcük bilgileri ve dil gelişimleri arasında istatistiksel açıdan anlamlı bir ilişki bulunamamıştır. Öykü kitabının etkili okunmasının dil gelişimi ile ilişkisi farklı çalışmalarda ele alınabilir. Çocukların yaşadığı ev ortamı ve aile özellikleri daha ayrıntılı incelenerek, çocukların dil gelişimlerinin ev ve okul ortamı ile birlikte değerlendirildiği çalışmalar yapılabilir. Bu çalışmada kitap okuma etkinliklerinde öğretmenlerin davranışları ve uygulamalarına yer verilmiştir. Bundan sonraki çalışmalarda kitap okuma etkinliklerinde çocukların davranışlarııın da incelenmesi önerilmektedir. Ayrıca bu çalışmada, kitap okuma etkinliklerinin niteliğinin dil gelişiminin önemli bir bileşeni olan sesbilgisel farkındalık ile ilişkisi incelenmemiştir. Diğer çalışmalarda kitap okuma etkinliklerinde çocukların sesbilgisel farkındalığı ile ilişkili olabilecek öğretmen davranışları incelenebilir. Çocukların fonolojik farkındalıklarını geliştirmek için resimli öykü kitaplarının nasıl kullanılması gerektiğini ile ilgili yöntemleri içeren deneysel çalışmalar yapılabilir. Buna ek olarak bundan sonra yapılacak olan çalışmalarda, kitap okuma etkinliklerinin erken okuryazarlık becerileri ile ilişkisi incelenebilir, bu becerilerin gelişimini kitap okuma etkinlikleri açısından ele alan deneysel çalışmalar yapılabilir. Öğretmenlerin çocukların ifade edici dillerini desteklemesine yönelik araştırmalar gerçekleştirilebilir.

\section{Araştırma ve Yayın Etiği}

Bu çalışmada "Yükseköğretim Kurumları Bilimsel Araştırma ve Yayın Etiği Yönergesi" kapsamında uyulması belirtilen tüm kurallara uyulmuştur. Yönergenin ikinci bölümü olan "Bilimsel Araştırma ve Yayın Etiğine Aykırı Eylemler" başlığı altında belirtilen eylemlerden hiçbiri gerçekleştirilmemiştir.

\section{Etik Kurul izni}

Kurul adı = Hacettepe Üniversitesi

Karar tarihi $=26.04 .2016$

Belge sayı numarası $=431-1386$

\section{Yazarların Katkı Oranı}

Birinci yazar (\%60) araştırmanın literatür taramasından araştırmanın son halini almasına kadar bütün bölümlerine katkı sağlamıştır. İkinci yazar (\%40) ise araştırmanın fikir aşamasından araştırmanın tamamlanmasına kadar fikren ve geri bildirimlerle katkı sağlamıştır.

\section{Çıkar Çatışması}

Bu araştırmada çıkar çatışması oluşturacak herhangi bir durum söz konusu değildir.

\section{Destek ve Teşekkür}

Bu araştırma, TÜBITAK BIDEB Yurtiçi Doktora Burs Programı desteği ile gerçekleştirilmiştir. Doktora sürecimde burs vererek beni finansal olarak destekleyen TÜBITAK'a teşekkürlerimi sunarım.

\section{Kaynaklar}

Aram, D., \& Shapira, R. (2012). Parent-child shared book reading and socio-emotional development. Italian Journal of Family Education, 2, 55-66.

Arı, R. (2018). Eğitim psikolojsi gelişim ve öğrenme. Ankara: Nobel Yayıncılık.

Armbruster, B. B., Lehr, F. \& Osborn, J. (2006). A child becomes a reader: Kindergarten through grade 3. https://lincs.ed.gov/publications/pdf/reading_pre.pdf adresinden erişilmiştir.

Barnes, E. M., Grifenhagen, J. F. \& Dickinson, D. K. (2016). Academic language in early childhood classrooms. The Reading Teacher, 70(1), 39-48. 
Bassa, Z. (2013). Çocuk kitaplarında resimleme. M. Gönen (Ed.), Çocuk edebiyatı (s. 179-221) içinde. Ankara: Eğiten Kitap.

Bay, D. N ve Çetin Şimşek, Ö. (2014). Storybook reading strategies of preschool teachers in the USA and Turkey. International Journal of Education and Research, 7(2), 41-54.

Beals, D. E., De Temple, J. M. ve Dickinson, D. (1994). Talking and listening that support early literacy development of children from low-income families. D. Dickinson (Ed.), Bridges to literacy: Approaches to supporting child and family literacy içinde (s.30-40). Cambridge, MA: Basil Blackwell.

Berger, L. M., Paxson, C., \& Waldfogel, J. (2009). Income and child development. Children And Youth Services Review, 31(9), 978-989.

Berüment, S. K. ve Güven, A. (2010). Tifaldi Türkçe ifade edici ve alıcı dil testi. Ankara: Türk Psikologlar Derneği.

Biemiller, A. (2006). Vocabulary development and instruction: A prerequisite for school learning. Dickinson, D. K. \& Neuman, S. B. (Ed.), Handbook of early literacy research içinde (s.41-51). New York, NY: Guilford Press.

Bowers, E. P. \& Vasilyeva, M. (2011). The relation between teacher input and the lexical growth of preschoolers. Applied Psycholinguistics, 32, 221-247.

Bredekamp, S. (2015). Erken çocukluk eğitiminde etkili uygulamalar. (H. Z. İnan ve T. İnan, Çev. Ed.). Ankara: Nobel Akademi Yayıncilık.

Bruning, R. H., Schraw, G. J. \& Norby, M. M. (2014). Bilişsel psikoloji ve öğretim (Z. N. Ersözlü ve R. Ülker, Çev. Ed.). Ankara: Nobel Akademik Yayıncılık.

Bus, A. G., \& Van IJzendoorn, M. H. (1995). Mothers reading to their 3-year-olds: The role of motherchild attachment security in becoming literate. Reading Research Quarterly, 30, 998-1015.

Bus, A. G., Van IJzendoorn M. H., \& Pellegrini A.D. (1995). Joint book reading makes for success in learning to read: A meta-analysis on intergenerational transmission of literacy. Review of Educational Research, 65(1), 1-21.

Catts, H.W., Fey, M. E., Zhang, X., \& Tomblin, B. (2001). Estimating the risk of future reading difficulties in kindergarten children: A research-based model and its clinical implementation. Language, Speech, and Hearing Services in Schools, 32, 38-50.

Chapman, R. S. (2000). Children's language learning: an interactionist perspective. Journal of Child Psychology and Psychiatry, 41, 33-54.

Christensen, D., Zubrick, S. R., Lawrence, D., Mitrou, F., \& Taylor, C. L. (2014). Risk factors for low receptive vocabulary abilities in the preschool and early school years in the longitudinal study of Australian children. PLoS One, 9(7): e101476.

Connor, C. M., Morrison, F. J. \& Slominski, L. (2006). Preschool instruction and children's emergent literacy growth. Journal of Educational Psychology, 98, 665-689.

Coyne, M. D., Simmons, D. C., Kame'enui, E. J., \& Stoolmiller, M. (2004). Teaching vocabulary during shared storybook readings: An examination of differential effects. Exceptionality, 12(3), 145-162.

Crain Thoreson, C., Dahlin, M. P., \& Powell, T. A. (2001). Parent-child interaction in three conversational contexts: Variations in style and strategy. New Directions for Child and Adolescent Development, 92, 23-38.

Curby, T. W., Grimm, K. J., \& Pianta, R. C. (2010). Stability and change in early childhood classroom interactions during the first two hours of a day. Early Childhood Research Quarterly, 25(3), 373384.

De Temple, J. \& Snow, C. E. (2003). Learning words from books. A. van Kleeck, S.A. Stahl \& E.B. Bauer (Ed.), On reading books to children: Parents and teachers içinde (s.16-36). Mahwah, NJ: Lawrence Erlbaum Associates.

DeBaryshe, B. D. (1993). Joint picture-book reading correlates of early oral language skill. Journal of Child Language, 20(2), 455-461.

DeBruin Parecki, A. (1999). Assessing adult/child storybook reading practices. Erişim Adresi: http://www.ciera.org/library/reports/inquiry-2/2-004/2-004.pdf 
Kitap Okuma Etkinliklerinin ve Resimli Öykü Kitaplarının Niteliği ile Sosyoekonomik Açıdan Dezavantajlı Çocukların Dil Gelişimleri Arasındaki ilişki

Deniz, A. ve Gönen, M. S. (2020). Resimli öykü kitaplarını değerlendirme ölçeğinin geliştirilmesi: Geçerlik ve güvenirlik çalışması. Erken Çocukluk Çalışmaları Dergisi, 4(2), 88-116.

Diamant Cohen, B. \& Hetrick, M. A. (2013). Transforming preschool storytime. Chicago, IL: NealSchuman.

Dickinson, D. K. \& Tabors, P. O. (2001). Beginning literacy with language. Baltimore: Brookes Publishing.

Dickinson, D. K., \& Keebler, R. (1989). Variation in preschool teachers' styles of reading books. Discourse Processes, 12(3), 353-375.

Dickinson, D. K., \& Smith, M. W. (1991). Preschool talk: Patterns of teacher-child interaction in early childhood classrooms. Journal of Research in Childhood Education, 6(1), 20-29.

Dickinson, D. K., Anastasopolous, L., McCabe, A., Peisner-Feinberg, E. S., \& Poe, M. D. (2003). The comprehensive language approach to early literacy: The interrelationships among vocabulary, phonological sensitivity, and print knowledge among preschool-aged children. Journal of Educational Psychology, 93, 465-481.

Dickinson, D. K., Cote, L., \& Smith, M. W. (1993). Learning vocabulary in preschool: Social and discourse contexts affecting vocabulary growth. New Directions for Child and Adolescent Development, 61, 67-78.

Dixon, J. A., \& Marchman, V. A. (2007). Grammar and the lexicon: Developmental ordering in language acquisition. Child Development, 78(1), 190-212.

Ergin, B. (2012). 5-6 yaş çocuklarının dil gelişim düzeyleri ile sosyal kabul durumları arasındaki ilişkinin incelenmesi (Yayımlanmamış yüksek lisans tezi). Selçuk Üniversitesi, Konya.

Ergin, T. (2020). Bilişsel gelişim. H. Ergin ve S. A. Yıldız (Ed.), Gelişim psikolojisi içinde (s.104-143). Ankara: Nobel Yayıncilık.

Ergül, C., Akoğlu, G., Sarıca, D. A., Tufan, M. ve Karaman, G. (2015). Ana sınıflarında gerçekleştirilen birlikte kitap okuma etkinliklerinin "etkileşimli kitap okuma" bağlamında incelenmesi. Mersin Üniversitesi Eğitim Fakültesi Dergisi, 11(3), 603-619.

Farkas, G., \& Beron, K. (2004). The detailed age trajectory of oral vocabulary knowledge: Differences by class and race. Social Science Research, 33(3), 464-497.

Fisher, D., Flood, J., Lapp. D. \& Frey, N. (2004). Interactive Read- alouds: Is there a common set of implementation practices? The Reading Teacher, 58, 8-17.

Gest, S. D., Holland Coviello, R., Welsh, J. A., Eicher Catt, D. L., \& Gill, S. (2006). Language development subcontexts in Head Start classrooms: Distinctive patterns of teacher talk during free play, mealtime, and book reading. Early Education and Development, 17, 293-315.

Gianvecchio, L. \& French, L. (2002). Sustained attention, inattention, receptive language, and story interruptions in preschool Head Start story time. Applied Developmental Psychology, 23, 393-407.

Girolametto, L., Weitzman, E., \& Greenberg, J. (2003). Training day care staff to facilitate children's language. American Journal of Speech-Language Pathology, 12, 299-311.

Gonzalez, J. E., Pollard-Durodola, S., Simmons, D. C., Taylor, A. B., Davis, M. J., Fogarty, M., \& Simmons, L. (2014). Enhancing preschool children's vocabulary: Effects of teacher talk before, during and after shared reading. Early Childhood Research Quarterly, 29(2), 214-226.

Goodson, B.D., Layzer, C., Smith, W.C., \& Rimdzius, T. (2006). Observation measures of language and literacy instruction (OMLIT). Cambridge, MA: Abt Associates Inc.

Gönen, M. (2013). Cumhuriyet öncesi ve cumhuriyet döneminde okul öncesi çocuk edebiyatı. M. Gönen (Ed.), Çocuk edebiyatı içinde (s.15-31). Ankara: Eğiten Kitap.

Graf Estes, K., Edwards, J., \& Saffran, J. R. (2011). Phonotactic constraints on infant word learning. Infancy, 16(2), 180-197.

Hancock, M. R. (2007). Language arts: Extending the possibilities. Upper Saddle River, NJ: Pearson.

Hart, B. \& Risley, T. R. (1995) Meaningful differences in the everyday experience of young American children. Baltimore, MD: Paul H. Brookes Publishing Co.

Hart, B. \& Risley, T. R. (2003). The early catastrophe: The 30 million word gap by age 3. American Educator, 27(1), 4-9. 
Hayes, D. P., \& Ahrens, M. G. (1988). Vocabulary simplification for children: A special case of 'motherese'? Journal of Child Language, 15, 395-410.

Hindman, A. H., Wasik, B. A. \& Erhart, A. L. (2012). Shared book reading and Head Start preschoolers' vocabulary learning: The role of book-related discussion and curricular connections. Early Education and Development, 23(4), 451-474.

IRA \& NAEYC. (1998). Learning to Read and Write: Developmentally Appropriate Practices for Young Children: A joint position statement of the International Reading Association (IRA) and the National Association for the Education of Young Children (NAEYC) Adopted 1998. Young Children, 53(4), 30-46.

Işıkoğlu Erdoğan, N., Atan, A., Asar, H., Mumcular, F., Yüce, A., Kiraç, M. ve Kilimlioğlu, Ç. (2016). Ebeveyn ve öğretmenlerin birlikte hikâye okuma etkinliklerinin incelenmesi. Illköğretim Online, 15(1), 125-135.

Justice, L. M., Zucker, T. A. \& Sofka, A. E. (2010). Systematic assessment of book reading: SABR manual. Project Star. Sit together and read. Preschool Language and Literacy Research Lab. The Ohio State University College of Education and Human Ecology, Columbus, Ohio.

Justice, L., Sutton, M., Sofka, A. E., \& Pianta, R. C., (2005). The book reading assessment scoring system. Charlottesville, VA: University of Virginia Center for Advanced Study of Teaching and Learning, Preschool Language and Literacy Lab.

Kandır, A. ve Koçak Tümer, N. B. (2013). Farklı sosyo-ekonomik düzeydeki beş-altı yaş çocuklarının erken öğrenme becerilerinin incelenmesi. Sosyal Politika Çalışmaları, 7(30), 45-64.

Kandır, A. ve Orçan, M. (2009). Alt ve üst sosyo-ekonomik düzeydeki ailelerin beş-altı yaş çocuklarının erken öğrenme becerilerinin bazı değişkenler yönünden incelenmesi. Kuramsal Eğitimbilim, 2(1), $1-13$.

Karasar, N. (2020). Bilimsel araştırma yöntemi kavramlar ilkeler teknikler. Ankara: Nobel.

Karatay, H. (2011). Çocuk edebiyatı metinlerinde bulunması gereken özellikler. T. Şimşek (Ed.), Kuramdan uygulamaya çocuk edebiyatı el kitabı (s. 77-125) içinde. Ankara: Grafiker Yayınları.

Kindle, K. J. (2011). Same book, different experience: A comparison of shared reading in preschool classrooms. Journal of Language and Literacy Education, 7(1), 13-34.

Landry, S. H., Crawford, A., Gunnewig, S., \& Swank, P. R. (2001). Teacher behavior rating scale. Center for Improving the Readiness of Children for Learning and Education, University of Texas Health Science Center at Houston.

Lane, H. B. \& Wright, T. L. (2007). Maximizing the effectiveness of reading aloud. The Reading Teacher, 60(7), 668-675.

Lee, C. (2012). Size matters: Early vocabulary as a predictor of language and literacy competence. Applied Psycholinguistics, 32(1), 69-92.

Lee, V. E. \& Burkham, D. T. (2002). Inequality at the starting gate. Washington, DC: Economic Policy Institute.

Letts, C., Edwards, S., Sinka, I., Schaefer, B., \& Gibbons, W. (2013). Socio-economic status and language acquisition: children's performance on the new Reynell Developmental Language Scales. International Journal Of Language \& Communication Disorders, 48(2), 131-143.

Lipsky, M. (2011). Head start teachers' vocabulary instruction and language complexity during storybook reading: Predicting vocabulary outcomes of students in linguistically diverse classrooms (Yayımlanmamış doktora tezi). University of Miami, Miami.

Locke, A., Ginsborg, J., \& Peers, I. (2002). Development and disadvantage: Implications for the early years and beyond. International Journal of Language and Communication Disorders, 37, 3-15.

Lynch Brown M. C., Tomlinson M. C. \& Short G. K. (2011). Essentials of children's literature. Pearson.

Mac Naughton, G. \& Williams, G. (2009). Teaching young children: Choices in theory and practice. UK: McGraw-Hill Education.

Marchman, V. A., \& Fernald, A. (2008). Speed of word recognition and vocabulary knowledge in infancy predict cognitive and language outcomes in later childhood. Developmental Science, 11(3), F9F16. 
Kitap Okuma Etkinliklerinin ve Resimli Öykü Kitaplarının Niteliği ile Sosyoekonomik Açıdan Dezavantajlı Çocukların Dil Gelişimleri Arasındaki ilişki

Mascareño, M., Snow, C. E., Deunk, M. I., \& Bosker, R. J. (2016). Language complexity during readalouds and kindergartners' vocabulary and symbolic understanding. Journal of Applied Developmental Psychology, 44, 39-51.

Mashburn, A. J., Pianta, R. C., Hamre, B. K., Downer, J. T., Barbarin, O. A., Bryant, D., Burchinal, M., Early, D. M., \& Howes, C. (2008). Measures of classroom quality in prekindergarten and children's development of academic, language, and social skills. Child Development, 79(3), 732-749.

Massey, S. L., Pence, K. L., Justice, L. M., \& Bowles, R. P. (2008). Educators' use of cognitively challenging questions in economically disadvantaged preschool classroom contexts. Early Education and Development, 19(2), 340-360.

McBride, C. (2016). Children's literacy development a cross-cultural perspective on learning to read and write. London: Routledge.

MEB. (2013). Okul öncesi eğitimi programı. Millî Eğitim Bakanlığı Talim Terbiye Kurumu.

Mol, S. E., Bus, A. G., De Jong, M. T., \& Smeets, D. J. (2008). Added value of dialogic parent-child book readings: A meta-analysis. Early Education and Development, 19(1), 7-26.

Montag, J. L., Jones, M. N. \& Smith, L. B. (2015). The words children hear: Picture books and the statistics for language learning, Psychological Science, 26(9): 1489-1496.

Moschovaki, E., Meadows, S. \& Pellegrini, A. (2007). Teachers' affective presentation of children's books and young children's display of affective engagement during classroom book reading. European Journal of Psychology of Education, 12(4), 405-420.

National Early Literacy Panel. (2008). Developing early literacy: Report of the National Early Literacy Panel. Washington, DC: National Institute for Literacy.

Neuman, S. B., \& Roskos, K. A. (Ed.). (1998). Children achieving: Best practices in early literacy. Delaware: International Reading Association.

Oğuzkan, F. (2013). Çocuk edebiyatı. Ankara: Anı Yayıncılık.

Payne, A. C., Whitehurst, G. J., \& Angell, A. L. (1994). The role of home literacy environment in the development of language ability in preschool children from low-income families. Early Childhood Research Quarterly, 9(3-4), 427-440.

Peers, I. P., Lloyd, P., \& Foster, C. (2000). Clinical evaluation of language fundamentals - preschool. UK. London: Psychological Corporation.

Pianta, R. C., Nimetz, S. L., \& Bennett, E. (1997). Mother-child relationships, teacher-child relationships, and school outcomes in preschool and kindergarten. Early Childhood Research Quarterly, 12(3), 263-280.

Pinker, S., \& Jackendoff, R. (2005). The faculty of language: what's special about it?. Cognition, 95(2), 201-236.

Pressley, M., \& Hilden, K. (2002). How can children be taught to comprehend text better? M.L. Kamil, J.B. Manning, \& H.J. Walberg (Ed.), Successful reading instruction: Research in educational productivity içinde (s.33-51). Greenwich, CT: Information Age.

Price, L. H., Van Kleeck, A. \& Huberty, C.J. (2009). Talk during book sharing between parents and preschool children: A comparison between storybook and expository book conditions. Reading Research Quarterly, 44(2), 171-194.

Roy, P. \& Chiat, S. (2013). Teasing apart disadvantage from disorder The case of poor language. C.R. Marshall (Ed.), Current issues in developmental disorders current issues in developmental psychology içinde (s.125-150). London: Psychology Press.

Rush, K. L. (1999). Caregiver-child interactions and early literacy development of preschool children from low-income environments. Topics in Early Childhood Special Education, 19(1), 3-14.

Scarborough, H. (2001). Connecting early language and literacy to later reading (dis)abilities: Evidence, theory, and practice. S. B. Neuman \& D. K. Dickinson (Ed.), Handbook of early literacy research içinde (s.97-110). New York: Guilford Press.

Sénéchal, M. (1997). The differential effect of storybook reading on preschoolers' acquisition of expressive and receptive vocabulary. Journal of Child Language, 24, 123-138. 
Sénéchal, M., LeFevre, J., Thomas, E., \& Daley, K. (1998). Differential effects of home literacy experiences on the development of oral and written language. Reading Research Quarterly, 32, 96-116.

Sever, S. (2008). Çocuk ve edebiyat. İzmir: Tudem Yayınları.

Silverman, R., Crandell, J. D. \& Carlis, L. (2013). Read alouds and beyond: The effects of read aloud extension activities on vocabulary in Head Start classrooms. Early Education \& Development, 24(2), 98-122.

Song, S., Su, M., Kang, C., Liu, H., Zhang, Y., McBride Chang, C., ... \& Shu, H. (2015). Tracing children's vocabulary development from preschool through the school-age years: An 8-year longitudinal study. Developmental Science, 18(1), 119-131.

Storch, S. A., \& Whitehurst, G. J. (2002). Oral language and code-related precursors to reading: Evidence from a longitudinal structural model. Developmental Psychology, 38, 934-947.

Svensson, A. K. (2009, Mart). Reading books in preschool is taken for granted: But is it true?. NPFP/NERA Konferansında sunulan bildiri, Trondheim. Erişim Adresi: http://www.divaportal.org/smash/get/diva2:886830/FULLTEXT01.pdf

Tabors, P. O., Snow, C. E., \& Dickinson, D. K. (2001). Homes and schools together: Supporting language and literacy development. D.K. Dickinson \& P.O. Tabors (Ed.), Beginning literacy with language: Young children learning at home and school içinde (s.313-334). Baltimore, MD: Brookes Publishing.

Tepetaş Cengiz, Ş. (2015). Okul öncesi öğretmenlerinin resimli öykü kitabı okuma etkinlikleri ile çocukların dil gelişimleri arasındaki ilişkinin incelenmesi (Yayımlanmamış doktora tezi). Hacettepe Üniversitesi, Ankara.

Topbaş, S. ve Güven, S. (2011). Türkçe erken dil gelişimi testi (TEDIL). Ankara: Detay Yayıncılık.

Tüfekçi Can, D. (2014). Çocuk edebiyatı kuramsal yaklaşım. Konya: Eğitim Kitabevi

TÜiK. (2016). Satınalma Gücü Paritesi (SGP) kullanılarak hesaplanan gelire dayalı göreli yoksulluk sınırına göre yoksul sayıları, yoksulluk oranı ve yoksulluk açığı. Erişim Adresi: http://www.tuik.gov.tr/PreTablo.do?alt_id=1013

Van Hulle, C. A., Goldsmith, H. H., \& Lemery, K. S. (2004). Genetic, environmental, and gender effects on individual differences in toddler expressive language. Journal of Speech, Language, and Hearing Research, 47(4), 904-912.

Van Kleeck, A. (2008). Providing preschool foundations for later reading comprehension: The importance of and ideas for targeting inferencing in storybook-sharing interventions. Psychology in the Schools, 45(7), 627-643.

Van Kleeck, A., Gillam, R. B., Hamilton, L., \& McGrath, C. (1997). The relationship between middle-class parents' book-sharing discussion and their preschoolers' abstract language development. Journal of Speech, Language, and Hearing Research, 40(6), 1261-1271.

Van Kleeck, A., Vander Woude, J. \& Hammett, L. (2006). Fostering literal and inferential language skills in Head Start preschoolers with language impairment using scripted book-sharing discussion. American Journal of Speech-Language Pathology, 15, 85-96.

Verhallen, M. J. \& Bus, A. G. (2011). Young second language learners' visual attention to illustrations in storybooks. Journal of Early Childhood Literacy, 11(4), 480-500.

Walker, D., Greenwood, C. R., Hart, B., \& Carta, J. J. (1994). Improving the prediction of early school academic outcomes using socioeconomic status and early language production. Child Development, 65, 606-621.

Walsh, B. A. \& Blewitt, P. (2006). The effect of questioning style during storybook reading on novel vocabulary acquisition of preschoolers. Early Childhood Education Journal, 33(4), 273-278.

Wasik, B. A. (2010). What teachers can do to promote preschoolers' vocabulary development: Strategies from an effective language and literacy professional development coaching model. The Reading Teacher, 63(8), 621-633.

Yavuzer, H. (2018). Eğitim ve gelişim özellikleriyle okul çağı çocuğu. İstanbul: Remzi Kitabevi.

Yazgan İnanç, B., Bilgin, M. ve Kılıç Atıcı, M. (2020). Gelişim psikolojisi. Ankara: Pegem Akademi. 
Kitap Okuma Etkinliklerinin ve Resimli Öykü Kitaplarının Niteliği ile Sosyoekonomik Açıdan Dezavantajlı Çocukların Dil Gelişimleri Arasındaki ilişki

Yıldırım, A. (2008). Okul öncesi eğitim kurumlarından yararlanmayan 4-5 yaş çocuklarının dil gelişsimini etkileyen faktörlerin incelenmesi (Konya ili örneği) (Yayımlanmamış yüksek lisans tezi). Selçuk Üniversitesi, Konya.

Zucker, T. A., Justice, L. M., Piasta, S. B., \& Kaderavek, J. N. (2010). Preschool teacher's literal and inferential questions and children's responses during whole class shared reading. Early Childhood Research Quarterly, 25, 65-83.

\section{Introduction}

\section{Extended Abstract}

The preschool years are considered a particularly critical time for the development of children's language skills. Although many factors may affect language development, studies report the major influence of socioeconomic status on language development as language development of children with lower socioeconomic status is low compared with the language development of children with middle and upper socioeconomic status (Biemiller, 2006; Hart \& Risley, 1995, 2003; Kandır \& Koçak Tümer, 2013; Kandır \& Orçan, 2009; Lee \& Burkham, 2002; Walker et al., 1994). Therefore, it is very important to support the development of the language skills of children from low-income families, especially at preschool age, as they may be at risk in terms of language development.

Teachers are important role models for children's language development and the most important activities to support preschool children's language skills are reading activities (National Early Literacy Panel, 2008). Book reading activities are considered "the most essential activity for children to acquire reading skills" (IRA \& NAEYC, 1998). Cognitively supportive talk about using comprehensive language and vocabulary occurs most frequently in book reading activities compared with other activities (Gest et al., 2006).

Studies show that reading activities that use rich language in preschool education contribute to children's language development (Dickinson et al., 2003; Dickinson \& Tabors, 2001). More interactions and language enrichment in the educational environment have a positive effect on children's vocabulary development (Dickinson, Cote, \& Smith, 1993; Rush, 1999). Children who hear more words learn more words, and, as their vocabulary grows, it is easier for them to learn new words (De Temple \& Snow, 2003). Children from risk groups, low-income families, or from different cultural backgrounds are the ones who need the experience of reading the most. A large number of bookreading activities should be done for those children to use the language at a higher level (Svensson, 2009).

A well-planned book reading activity includes practices, such as asking open-ended questions, connecting the reading to children's lives and experiences, and asking questions that require a connection to the characters and other books. Books read with attention to these practices help children express themselves effectively (Pressley \& Hilden, 2002). Rehearing the syntactic structures and grammatical rules that children hear and use in spoken language through texts in books increases their familiarity with the structure of language; language development is supported in this way. Storybooks for children should have the richness that children need regarding language development; it is necessary to select qualified books about these characteristics (Barnes, Grifenhagen, \& Dickinson, 2016; Tüfekçi Can, 2014). When examining the relevant literature, one comes across studies that investigate the relationship between book reading activities and children's language development and early literacy skills (Beals, De Temple, \& Dickinson, 1994; Connor, Morison, \& Slomonski, 2006; Hindman, Wasik, \& Erhart, 2012; Lipsky, 2011; Mascareño et al., 2016; Tepetaş Cengiz, 2015). In these studies, the focus is mostly on receptive language vocabulary.

This study aims to investigate the relationship between the qualities of read-aloud activities and picture books and receptive and expressive vocabulary and language development of 5-year-old children from low-income families.

\section{Method}

The study was conducted using the relational survey model. The model is used to determine the existence or degree of covariance among variables. The relationships determined through the 
model do not point out cause-and-effect relationships among variables; the model is used to indicate how a change in one variable predicts the other (Karasar, 2020).

The study was conducted with 181 children aged five years and 21 preschool teachers. The TIFALDI scale was used to determine the children's receptive and expressive vocabulary, and the TEDIL scale was used to determine their receptive and expressive language development. The Read-Aloud Teacher Assessment Form was developed by the researchers to rate the read-aloud activities, and the Picture Book Assessment Scale was used to assess the picture books read during the activity and in the book center.

\section{Results and Discussion}

The findings showed that there was a statistically significant and positive relation between the quality of receptive language, expressive language, book reading environment, and picture books and the receptive and expressive vocabulary and language development of the children. There was no statistically significant relation between the quality of the effective reading of stories and the children's receptive and expressive vocabulary and language development. The variables that significantly predicted the verbal language performance of the five-year-old children were family monthly income, family frequency of reading books aloud, their receptive and expressive vocabulary, and the teacher's points to support the development of children's expressive language.

The study revealed that teachers' talk about the stories in the book reading activities, using a complex language and their being models in using language impact children's language development are consonant with previous studies (Beals et al., 1994; Bowers \& Vasilyeva, 2011; Gest et al., 2006; Hindman et al., 2012; Mascareño et al., 2016; Tepetaş Cengiz, 2015). The richness of the words and language used by teachers in preschool education is related to children's expressive vocabulary (Bowers \& Vasilyeva, 2011). In addition, reading activities create opportunities for teachers to ask cognitively thought-provoking questions (Massey et al., 2008). Asking open-ended questions related to the story has positive effects on the vocabulary of pre-school children at risk (Bay \& Şimşek Çetin, 2015; Van Kleeck et al., 2006). Studies have shown that the greatest increase in vocabulary acquisition occurs when children are asked questions during the book reading activity (Walsh \& Blewitt, 2006; Gonzalez et al., 2014; Van Kleeck, 2008). In their study, Zucker, Justice, Piasta \& Kaderavek (2010) showed that preschool teachers could use inference-based questions to encourage children to participate in more complex conversations in book reading activities.

Further studies may be conducted with younger age groups to examine the effect of school and home environments and family characteristics. Teacher behaviors on children's phonological awareness during book reading activities may also be examined. Experimental studies may be conducted on how picture books should be used to improve children's phonological awareness. The relationship between book reading activities and early literacy skills may be carried out to examine the development of those skills. 